\title{
Produkcja podmiotów homonormatywnych? Dyskurs rynkowy wokół regulacji prawnej związków partnerskich w Polsce i małżeństw jednopłciowych w Stanach Zjednoczonych w 2013 roku
}

\section{Monika Sznel}

\author{
Uniwersytet Warszawski
}

\begin{abstract}
[Artkuł ukazał się wcześniej na łamach InterAliów w sekcji artykuły bieżące, tutaj.]
Czy wolny rynek może mieć potencjat emancypacyjny dla osób niewpisujących się w tradycyjny wzorzec ról genderowych? W niniejszym artykule przyjrzę się dwóm debatom: wokót legalizacji związków partnerskich w Polsce oraz tej dotyczącej matżeństw jednoptciowych w Stanach Zjednoczonych w kontekście wptywu, jaki dyskurs wolnorynkowy może mieć na wspótczesne obywatelstwo seksualne. Wielkomiejska homonormatywność jest jednym z produktów kapitalistycznej gospodarki, gdzie terminy takie jak "klasa kreatywna", "tolerancja" i "różnorodność" stanowia komponenty globalnej produkcji ekskluzywnej tożsamości homonormatywnej.
\end{abstract}

Słowa kluczowe: związki partnerskie, Polska, USA, neoliberalizm, homonormatywność

Jednym z najgłośniejszych wydarzeń medialnych pierwszego kwartału 2013 roku były w Polsce obrady Sejmu nad propozycjami ustaw o związkach partnerskich ${ }^{1}$. Projekty zgłosiły trzy partie polityczne: Platforma Obywatelska, Sojusz Lewicy Demokratycznej i Ruch Palikota ${ }^{2}$. Grupa Inicjatywna ds. związków partnerskich ${ }^{3}$ od 2009 roku gromadziła argumenty prawne, ekonomiczne i statystyczne ukazujące zasadność wprowadzenia nowych regulacji prawnych umożliwiających osobom pozostającym w relacjach pozamałżeńskich korzystanie z podobnych praw, co polscy małżonkowie: kobieta i mężczyzna4. Inicjatywa ustawodawcza, którą w 2004 roku podjęła ówczesna senator Maria Szyszkowska ${ }^{5}$, pokazała, że obowiązujące prawo nie odzwierciedla sytuacji polskich rodzin w XXI wieku. Chroniony na mocy konstytucji model rodziny nuklearnej bazującej na małżeństwie kobiety

${ }^{1}$ Związek partnerski odnosi się zarówno do relacji jedno- jak i dwupłciowych, niemniej, w Polsce debata skupiała się przede wszystkim na relacjach jednopłciowych; zatem w niniejszym tekście, pisząc o związku partnerskim będę miała na myśli związki pomiędzy osobami tej samej płci.

2 Projekt PO dopuszczał rejestrację związków par hetero- i homoseksualnych w Urzędzie Stanu Cywilnego i gwarantował im wspólność majątkową, prawo do dziedziczenia, dostęp do informacji medycznej partnera, wypłatę z rachunku bankowego po śmierci partnera, prawo o decydowania o pochówku. Projekty ustaw SLD i Ruchu Palikota dopuszczały wspólne opodatkowanie, a także prawo do objęcia rentą rodzinną, wspólnym ubezpieczeniem zdrowotnym i przyjęcie nazwiska partnera. Żadna z propozycji nie odnosiła się do zagadnienia adopcji dzieci. z treścią trzech propozycji można zapoznać się na http://www.sejm.gov.pl/sejm7.nsf/page.xsp/przeglad_ustaw [dostęp: 22.03.2014].

3 Pozarządowa grupa powstała w 2009 roku i stawiająca sobie za cel przeprowadzenie konsultacji społecznych w sprawie legalizacji związków partnerskich. Członkowie Grupy uczestniczyli również w pisaniu projektów ustaw we współpracy z SLD i Ruchem Palikota.

4 Artykuł 18 Konstytucji RP określa małżeństwo jako związek kobiety i mężczyzny. Projekty ustaw dotyczyły legalizacji związków partnerskich, które są odmienną formą prawnej regulacji relacji międzyludzkich, chodziło o wprowadzenie nowej kategorii umowy cywilnoprawnej.

${ }^{5}$ Maria Szyszkowska - polska filozof, polityk i działaczka społeczna. Stworzony przez nią projekt ustawy o umowach związków partnerskich został przyjęty przez Senat, jednak w Sejmie został usunięty z porządku obrad decyzją ówczesnego Marszałka Sejmu - Włodzimierza Cimoszewicza; nie odbyło się ani jedno jego czytanie. 
i mężczyzny nigdy nie był ${ }^{6}$ - i tym bardziej nie jest współcześnie - jedynym sposobem tworzenia rodziny (Slany 2002).

Coraz liczniejsze w Polsce badania z zakresu gender studies i studiów nad rodziną pokazują, że od blisko 20 lat $^{7}$ definicja rodziny nieustannie poszerza swoje signifié. Rodziny patchworkowe, samotnie wychowujący dzieci rodzice (nie tylko kobiety), rodziny z wyboru, związki homoseksualne czy kohabitaty to tylko niektóre z nowych modeli rodziny obecnych w życiu społecznym Polaków (Kluczyńska 2013; Mizielińska, Stasińska 2013). Ubiegłoroczna debata wokół związków partnerskich otworzyła puszkę Pandory: okazało się, że faktycznym polem konfliktu jest polska tożsamość i definiowanie, kto do polskiego społeczeństwa może należeć i na jakich zasadach (zob. Kościańska 2012a). Seksualność obywateli to soczewka, dzięki której możemy przyglądać się procesom społecznym i indywidualnym praktykom, zaś regulowana przez państwo, jest jednym z komponentów pożądanego modelu tożsamości obywateli (Weeks 2012: 45-46). W niniejszym artykule mogłabym podążyć ścieżką wyznaczoną na łamach czasopisma "InterAlia” przez Joannę Mizielińską i Agatę Stasińską (Mizielińska, Stasińska 2013), zestawiając dyskurs prasowy wokół związków partnerskich z kampanią społeczną "Rodzice, odważcie się mówić”, niemniej postanowiłam skorzystać z czasowej zbieżności polskiej dyskusji z tą trwającą w Stanach Zjednoczonych na temat małżeństw jednopłciowych i przysługujących im praw federalnych i stanowych.

Sąd Najwyższy szczebla federalnego w Stanach Zjednoczonych wydał 26 czerwca 2013 roku dwa precedensowe orzeczenia. Pierwsze z nich, w sprawie United States $v$. Windsor, mówiące o godzącej w Piątą Poprawkę do Konstytucji Stanów Zjednoczonych ustawie federalnej "Defense of Marriage Act" (w skrócie: DOMA; ustawa o obronie małżeństwa), oraz drugie, dotyczące sprawy Hollingsworth $v$. Perry, na powrót legalizujące zawieranie małżeństw jednopłciowych w stanie Kalifornia. W obu sprawach argumenty merytoryczne spotykały się ze światopoglądowymi, co nadało dyskusji wielowymiarowy charakter, jednak nie odtworzenie całego dyskursu publicznego będzie moim celem. Zgromadzę narracje "za” związkami partnerskimi obecne w polskim dyskursie medialnym $w$ trakcie sejmowej debaty i skupię się przede wszystkim na emancypacyjnej roli przypisywanej kapitalizmowi w tworzeniu podmiotów homonormatywnych ${ }^{8}$ (Brown 2012, Duggan 2002). Podążając tym tropem, szczegółowej analizie poddam uczestnictwo w debacie wielkich marek rynkowych i prywatnych pracodawców udzielających poparcia osobom homoseksualnym w Stanach Zjednoczonych, którego zabrakło w Polsce. Zobaczymy, jak giganci biznesu przekonują do małżeństw jednopłciowych, co mogą na tym zyskać i jacy aktorzy biorą udział w definiowaniu seksual-

${ }^{6}$ Książki autorstwa Krzysztofa Tomasika (Gejerel. Mniejszości seksualne w PRL-u, Homobiografie) sprzeciwiają się narracjom przeciwników homoseksualności postulującym, jakoby miała ona nadejść z liberalnego Zachodu zaraz po rozpoczęciu procesu transformacji ustrojowej. Tomasik pokazuje, że relacje homoerotyczne istniały w Polsce także przed 1989 rokiem.

7 Studia nad seksualnością mają istotny związek z transformacją ustrojową, która dzięki dynamicznym i często radykalnym zmianom społecznym (migracje zarobkowe, urbanizacja, turystyka itp.) przyczyniła się do różnicowania stylów życia i problematyzowania przyjętych na mocy tradycji wzorców społecznych.

8 Termin "homonormatywność" wprowadziła Lisa Duggan (2002) na określenie przesunięcia w zachodniej (homo)seksualnej polityce tożsamościowej, którego początki sięgają lat 90. XX wieku. Zdeterminowana przez neoliberalizm (jako model gospodarczy i ideologię) homonormatywność nie stara się kwestionować dominujących heteronormatywnych wzorów genderowych i instytucji publicznych, lecz wpisać się wich porządek poprzez poszerzanie praw cywilnych (sfera publiczna) i możliwości konsumpcyjnych (sfera prywatna) nieheteronormatwnych jednostek, jednocześnie wyciszając wolnościowy i polityczny wymiar ruchów emancypacyjnych grup nieheteronormatywnych kwestionujących normalizujące i wykluczające modele homo- i heteronormatywności. 
ności obywateli oraz szerzej - tworzeniu współczesnego obywatelstwa, by w końcowej części artykułu poddać refleksji i zakwestionować emancypacyjny charakter wolnego rynku. Najpierw jednak postaram się zrekapitulować linię argumentacji „przeciw” ustawie, które pojawiły się zarówno w sejmowej debacie, jak i dyskursie medialnym ${ }^{9}$.

\section{„Jałowe” i „nielegalne” związki tworzące „homolobby”}

Głównym zarzutem oponentów ustawy dotyczącej legalizacji związków partnerskich była jej sprzeczność z Konstytucją RP. Treść ustawy miałaby godzić w zapis Art. 18 ustawy zasadniczej, który brzmi: „Małżeństwo jako związek kobiety i mężczyzny, rodzina, macierzyństwo i rodzicielstwo znajdują się pod ochroną i opieką Rzeczypospolitej Polskiej" i tym samym miałaby stanowić zagrożenie dla chronionej prawem instytucji rodziny. Kolejnym istotnym kontrargumentem okazała się "jałowość"10 związków partnerskich, które nie przyczyniają się do polepszenia sytuacji gospodarczej kraju, a wręcz działają na jej niekorzyść, postulując serię praw cywilno-gospodarczych; "jałowość" związków partnerskich miałaby polegać również na niemożności prokreacji i posiadania dzieci przez pary jednopłciowe ${ }^{11}$. Niektóre głosy - odwołujące się do dyskursu medycznego - wskazywały, że homoseksualność jest rodzajem dewiacji, choroby (padały porównania z zoofilią) i tym samym stanem nienaturalnym, niezgodnym z biologicznie zdeterminowaną normą, pomimo że od kilkudziesięciu lat nie jest klasyfikowana przez świat medycyny jako schorzenie ${ }^{12}$. w podobnym tonie wypowiadał się jeden z pierwszych czarnoskórych ${ }^{13}$ posłów na Sejm RP, John Godson, który podkreś-

${ }^{9}$ Biorę pod uwagę wypowiedzi ministra sprawiedliwości Jarosława Gowina, posłów Johna Godsona i Krystyny Pawłowicz, byłego prezydenta RP Lecha Wałęsy oraz artykuły, które ukazały się na łamach "Naszego Dziennika”, "Uważam Rze” i „Do Rzeczy".

10 Poseł (jak sama prosi, by ją nazywać, sygnalizując jednocześnie brak zrozumienia studiów nad płcią kulturową) Krystyna Pawłowicz spotkała się z ogromną krytyką polityków, publicystów, środowisk uniwersyteckich (Pawłowicz jest doktorem habilitowanym nauk prawnych, nauczycielem akademickim) po tym, jak z sejmowej mównicy padały z jej ust stwierdzenia: "Zjawisko związków jednopłciowych jest sprzeczne z naturą, projekty są sprzeczne z Konstytucją, zmierzają do jej obejścia, są szkodliwe, niesprawiedliwe, naruszają, zasadę równości, prawo do intymności, ekshibicjonistycznie pozwalają obnosić w przestrzeni publicznej skłonności seksualne, czym naruszają poczucie estetyki i moralności większości Polaków", czy „Społeczeństwo nie może jednak fundować słodkiego życia nietrwałym, jałowym związkom osób, z których społeczeństwo nie ma żadnego pożytku, a tylko ze względu na łączącą ich więź seksualną [...] [osoby te] nie mogą jednak zmuszać państwa do odwrócenia naturalnego porządku rzeczy i uznanych społecznie priorytetów większości służących jego trwaniu" (zob. wypowiedź Krystyny Pawłowicz podczas sejmowej debaty z dnia 24 stycznia 2013 roku https://www.youtube.com/ watch?v=wnOMCC1GpTE) [dostęp: 30.07.2014].

$11 \mathrm{~W}$ innej wypowiedzi Pawłowicz stwierdziła, że "ktoś, kto nie jest katolikiem nie zrozumie polskiego społeczeństwa" (zob. http://natemat.pl/55363,krystyna-pawlowicz-ktos-kto-nie-jest-katolikiem-nie-zrozumie-polskiego-spoleczenstwa; dostęp: 30.07.2014). Jej argument dotyczący „jałowości” związków partnerskich odnosi się zatem do oficjalnego stanowiska Kościoła Katolickiego, który definiuje homoseksualizm jako dewiację, która nie prowadzi do prokreacji będącej jednym z głównych celów małżeństwa między kobietą a mężczyzną.

12 Homoseksualność wykreślono w 1974 roku z listy zaburzeń psychicznych DSM (klasyfikacja zaburzeń psychicznych Amerykańskiego Towarzystwa Psychiatrycznego) oraz w 1990 roku z Międzynarodowej Statystycznej Klasyfikacji Chorób i Problemów Zdrowotnych Światowej Organizacji Zdrowia. w 2006 roku Polskie Towarzystwo Seksuologiczne, „zaniepokojone krzywdzącym wpływem społecznych uprzedzeń na funkcjonowanie psychiczne i społeczne osób homoseksualnych i biseksualnych", wydało oficjalne oświadczenie przypominające o tych zmianach. Zob. http://www.bezuprzedzen.org/ doc/Stanowisko PTS.pdf [dostęp: 22.09.2013].

13 Odnotowanie koloru skóry posła Godsona jest w kontekście poruszanego tematu istotne, bowiem dyskryminacja ze względu na orientację seksualną, którą stosuje w swoich wypowiedziach John Godson (nagrodzony w 2011 roku "Srebrnymi Ustami" przez słuchaczy Programu III Polskiego Radia za wypowiedź promującą wielodzietne rodziny nuklearne), jest - zarówno w świetle prawa polskiego jak i europejskiego - zakazana, podobnie jak dyskryminacja ze względu na pochodzenie etniczne czy kolor skóry. w artykule 32 Konstytucji czytamy iż: „Nikt nie może być dyskryminowany w życiu politycznym, społecznym lub gospodarczym z jakiejkolwiek przyczyny", choć - jak wskazuje Zofia Jabłońska - przepis 
lał, że homoseksualność (Godson używał określenia "homoseksualizm”) nie może stanowić dopuszczalnej prawnie normy, bowiem byłoby to jednoznaczne z naruszeniem kanonu wartości tworzących polską tożsamość narodową. Ta zaś opiera się na fundamencie, jakim jest rodzina. Kaszubi, jedna z lepiej zintegrowanych grup etnicznych w Polsce, wystosowali do premiera (pochodzącego z Kaszub) apel, w którym wzywają do obrony fundamentalnych wartości: legalizacja związków partnerskich w znacznym stopniu przyczyni się do zachwiania ładu społecznego opartego o wartości chrześcijańskie ${ }^{14}$. Tego rodzaju stwierdzenia wykorzystują zabieg reifikacji i mitologizacji nuklearnej rodziny heteroseksualnej zakorzenionej w - częstokroć - wiejskim lub małomiasteczkowym pejzażu społeczno-ekonomicznym zrównując ją z "naturalną", jakoby istniejącą od zawsze, podczas gdy argumentującym w ten sposób umyka społeczna dynamika relacji międzyludzkich uzależnionych od czynników ekonomicznych, geograficznych czy światopoglądowych.

W prasie pojawiło się kilka artykułów, podnoszących argumenty analogiczne do powyższych, oraz narracja sugerująca istnienie "homolobby", wpływającego na kształt polskiego prawodawstwa i forsującego "ideologię homoseksualną"15. Ten rodzaj argumentacji jest szczególnie istotny dla dalszej części artykułu - sugeruje bowiem, że osoby homoseksualne to najczęściej ludzie pracujący w zawodach "kreatywnych": w branży związanej z mediami, kulturą, sztuką, ale także prawniczej czy bankowej ${ }^{16}$.

Mówienie o istnieniu homolobby w kontekście związków partnerskich kreuje negatywny ${ }^{17}$ wizerunek potencjalnych beneficjentów ustawy z uwagi na negatywną społeczną percepcję działalności lobbingowej w polskim kontekście w ogóle. Kategoria homolobby została błyskawicznie przejęta przez publicystów opowiadających się przeciw związkom partnerskim i poruszających się w dys-

artykułu nie może stanowić podstawy roszczenia (Zob. http://www.kph.org.pl/publikacje/raport dyskryminacja w zatrudnieniu.pdf; dostęp: 30.07.2014). Cechę tę posiada natomiast Ustawa o wdrożeniu niektórych przepisów Unii Europejskiej w zakresie równego traktowania, która odnosi się prawie do wszystkich obszarów aktywności zawodowej człowieka. Niemniej, zapisów ustawy nie stosuje się już między innymi do sfery życia prywatnego i rodzinnego, czy treści zawartych w środkach masowego przekazu (zob. Dz.U. 2010 nr 254 poz. 1700). w świetle niniejszego artykułu, uwaga ta nabiera również znaczenia w odniesieniu do debaty w Stanach Zjednoczonych, gdzie zwolennicy legalizacji małżeństw jednopłciowych porównują dyskryminację takiej formy związków cywilno-prawnych do dyskryminacji rasowej i zakazu małżeństw międzyetnicznych/międzyrasowych obowiązującego do 1967 roku.

14 "Nasz Dziennik", 05.04.2013. Zob. http://www.naszdziennik.pl/wp/28814,kaszubi-za-rodzina.html [dostęp: 22.03.2014].

15 Kategoria "homolobby" została wprowadzona do polskiego dyskursu w okolicach 2004 roku przez media katolickie obok takich terminów jak „ideologia homoseksualna” czy "homoideologia” (Kościańska 2012b), umiejscawiając homoseksualność obok zbrodniczych ideologii nacjonalistycznych i rasistowskich z nazizmem i faszyzmem włącznie. Obok takich sformułowań pojawia się też sformułowanie "homoherezja” - homoseksualizm jest odejściem od oficjalnej nauki Kościoła Katolickiego, która według Katechizmu Kościoła Katolickiego (obecna wersja - z późniejszymi poprawkami - obowiązuje od 1992 roku) definiuje homoseksualizm jako dewiację niezgodną z prawem naturalnym i przejaw nieczystości - na równi z pornografią czy masturbacją - i wskazuje, że jako taki nie może być zaaprobowany przez Kościół jako nie prowadzący do prokreacji; zob. artykuły 2357-2359 KKK). Zob. http://religia.onet.pl/wywiady,8/homo-lobby-ma-swoich-ludzi-nakluczowych-stanowiskach-w-kosciele,44528.html [dostęp: 22.03.2014].

16 Polecam uwadze dyskusję wokół wypowiedzi Joanny Szczepkowskiej o homolobby trzęsącym światem sztuki. Zob. Tajne homolobby, które trzęsie Polską, NaTemat.pl, 27.03.2013, http://natemat.pl/55785,tajne-homolobby-ktore-trzesie-polska [dostęp: 22.03.2014].

17 Lobbing ma w potocznym dyskursie zabarwienie negatywne, podczas gdy stanowi sankcjonowaną prawnie, dopuszczaną formę wpływu osób fizycznych i przedsiębiorstw na kształt prawodawstwa (na mocy ustawy dnia 7 lipca 2005 roku). o ile w Polsce negatywny stosunek do działalności lobbingowej został ukształtowany na skutek przekazów medialnych kilku afer sejmowych lat 90. I pierwszych, percepcja tej formy nacisku na legislatywę i egzekutywę w Stanach Zjednoczonych ma się o wiele lepiej, gdzie stanowi formę partycypacji obywateli w procesie stanowienia prawa (Adamus-Matuszyńska 2006). 
kursie ukazującym homoseksualność jako element moralnego zepsucia nadchodzącego do Polski z krajów Zachodu po 1989 roku wraz z liberalizacją obyczajowości i transformacją gospodarki kraju.

Autorzy argumentów przeciw ustawie ukazują homoseksualność i, w konsekwencji, związki partnerskie jako jeden z zachodnich „produktów”, który zaczął oddziaływać na polskie społeczeństwo wraz z rozpoczęciem transformacji ustrojowej. Transformacja umożliwiła Polsce udział w globalnej gospodarce, wprowadziła wolnorynkowy system gospodarczy i znacząco wpłynęła na sposób konstruowania jednostkowej tożsamości - zmiany te często określane w kategoriach modernizacji i nowoczesności zachwiały obrazem polskości jako tożsamości narodowej, która opierała się w dużej mierze na tradycji romantycznej, narodowowyzwoleńczej, z silnie zakorzenionymi rolami społecznymi przypisywanymi kobiecie, mężczyźnie i rodzinie (zob. Dunn 2008). Konstruowanie tych ról opierało się na tradycyjnym modelu i stanowiło o porządku, przewidywalności i powtarzalności jednostek "reprodukowanych" w heteronormatywnej matrycy (Butler 2008). Cielesność po dziś dzień (choć stosunkowo niedługo, bo od XIX wieku) ma kluczową rolę w definiowaniu seksualności, i zgodnie z taką konstrukcją płci kulturowej (w oparciu o płeć biologiczną) kobiety i mężczyźni mają określone powinności biologiczne i wynikające z nich obowiązki społeczne (Vance 2007). Wszystko, co niezgodne z takim modelem, było uznawane za dewiację, zachwianie normy, co często starano się wykazać w oparciu o dyskursy naukowe i eksperckie: medyczny czy psychologiczny. Sam "homoseksualista" został przecież stworzony przez XIX-wiecznych pionierów zachodniej medycyny i seksuologii jako typ osoby (Foucault 1995, Somerville 1994). Przedstawiciele tych dziedzin już dawno wzięli jednak rozbrat z patologizującymi i homofobicznymi dyskursami.

\section{Równe prawa dla równych ludzi.}

\section{Prawo europejskie, narracja postępu i nowoczesne style życia Polaków}

Większość obecnych w debacie medialnej ${ }^{18}$ argumentów przekonujących do legalizacji związków partnerskich była poprzedzona przesłanką: homoseksualność jest jedną z możliwych orientacji seksualnych i nie jest dewiacją ani chorobą ${ }^{19}$, podczas gdy - jak pisałam wcześniej - środowiska konserwatywne i prawicowe starały się wykazać, że jest odwrotnie. Począwszy od riposty wobec zarzutu niekonstytucyjności ustawy, przez argumenty ekonomiczne na rzecz związków partnerskich, po odniesienie się do homoseksualności jako jednego z wielu możliwych stylów życia - argumenty „za” tworzyły obraz homoseksualisty-ofiary, homoseksualisty świadomie tworzącego swoją tożsamość jednostki, a także oso swobodnie poruszającej się w wolnorynkowej rzeczywistości.

Pierwszą widoczną grupą osób zabierających głos w sprawie jest środowisko prawnicze. Ewa Łętowska - była rzeczniczka praw obywatelskich, sędzina Trybunału Konstytucyjnego - przekonywała, że wysuwanie argumentu niekonstytucyjności ustawy świadczyło o niemerytorycznej ${ }^{20}$ linii argumentacji. Przede wszystkim Art. 18 Konstytucji RP nie definiuje rodziny tylko jako małżeństwa kobiety

18 Odwoływać się będę do artykułów z czasopism: „Newsweek”, „Rzeczpospolita”, „Przekrój”, portali internetowych "Na Temat”, „Dziennik.pl”, „Dziennik opinii”, „Wyborcza.pl”, „Onet.pl”, „Gazeta.pl”.

19 Wypowiedzi prasowe popierające wprowadzenie związków były bliskie teorii konstruktywizmu społecznego, zgodnie z którym orientacja seksualna nie jest uwarunkowana biologicznie, wrodzona, ale konstruowana społecznie (Zob. Vance 2007).

20 Wielu komentatorów debaty sejmowej wskazywało, że jej niemerytoryczność wynikała z dominacji światopoglądu nad argumentami z zakresu prawa, co sprowadzało się do jego instrumentalnego użycia. 
i mężczyzny, zatem związki partnerskie - jako alternatywny do nuklearnego modelu rodziny - nie stanowią formy związku między dwiema osobami, która zagraża instytucji tradycyjnego małżeństwa. Ponadto, brak zapisu dotyczącego innych form związków między ludźmi w ustawie zasadniczej, w tym związków partnerskich, nie stanowi wykładni negatywnej: nie oznacza, że obowiązujące prawo ich zabrania. Mecenas Marcin Górski, który pracował nad odrzuconymi projektami ustaw dodawał, że artykuł 18 nakazuje chronić tylko jeden z wielu możliwych rodzajów tego, co nazywamy rodziną. Co więcej, artykuł 32 konstytucji mówi o zasadzie równości, równego traktowania i zakazie dyskryminacji, zatem wykluczenie innych modeli rodzin (w tym związków partnerskich) stanowi formę dyskryminacji zarówno w świetle konstytucji, jak i Europejskiej Konwencji Praw Człowieka. W podobnym tonie wypowiadała się Agnieszka Kozłowska-Rajewicz - doktor nauk medycznych, pełnomocniczka rządu ds. równego traktowania (PO) - która łączy zarysowany powyżej dyskurs ekspercki z linią argumentów ekonomicznych stanowiących drugą silną grupę "za" zwiążkami partnerskimi.

O ile środowiska przeciwne ustawie akcentowały, że jej wprowadzenie umożliwi osobom pozostającym w związkach partnerskich korzystanie z licznych praw zastrzeżonych dla specyficznej formy małżeństwa pomiędzy kobietą i mężczyzną ${ }^{21}$, których "społeczeństwo nie może fundować", tak zwolennicy ustawy wskazują również korzyści gospodarcze, jakie społeczeństwo i budżet państwa mogą czerpać z legalizacji związków partnerskich: doradcy podatkowi i pracownicy firm konsultingowych mówili między innymi o ulgach podatkowych, z których korzystają teraz "samotne matki", tworzące w rzeczywistości związki jednopłciowe, czy korzyściach mieszkaniowych związanych z przydziałem mieszkania służbowego dla osób pozostających w związku nieformalnym i podejmujących pracę w służbach regulowanych. Umożliwienie partnerom tworzenia związku zgodnego z własną tożsamością seksualną skutkowałoby również wzrostem poczucia bezpieczeństwa, stabilności - są to "miękkie" argumenty ekonomiczne oparte na założeniu, że szczęśliwy obywatel jest jednocześnie wydajnym podmiotem na rynku pracy.

Niezamężne kobiety samotnie wychowujące dzieci to zjednej strony grupa osób użyta dla intensyfikacji argumentu dotyczącego zysku dla budżetu państwa wynikającego z legalizacji zwiążków partnerskich („samotne matki”) ${ }^{22}$, z drugiej realna kategoria czy raczej jeden z nowych modeli funkcjonujących w Polsce rodzin. To jeden z wielu podmiotów niewpisujących się w konserwatywny model rodziny uprzywilejowany przez polskie prawo. Samotne matki również udzielały poparcia dla związków partnerskich, między innymi podczas demonstracji pod Sejmem RP23.

21 Prawa zastrzeżone obecnie dla małżeństw umożliwiają codzienne funkcjonowanie w ramach państwowych instytucji (wspólnota majątkowa, dziedziczenie, wspólne opodatkowanie) oraz decyzyjność w sytuacjach skrajnych dotyczących między innymi leczenia szpitalnego czy pochówku partnera.

22 W polskim prawodawstwie staranie się o adopcję dziecka przez pary homoseksualne nie jest dopuszczalne, niemniej osoby samotne, oficjalnie niebędące w związku małżeńskim mogą wystąpić z wnioskiem o adopcję, z czego często korzystają pary gejów lub lesbijek, chcące założyć rodzinę.

23 Demonstracja odbyła się w niedzielę 27 stycznia 2013 roku, tuż po odrzuceniu wszystkich projektów ustaw o związkach partnerskich. Została zorganizowana spontanicznie na Facebooku. Grafika promująca wydarzenie wykorzystywała plakat "W samo południe" zachęcający w 1989 roku do uczestnictwa w demokratycznych wyborach parlamentarnych. Organizatorzy demonstracji zdublowali Gary Coopera opatrując partnerów napisem "Solidarność XXI wieku. Wesprzyj związki partnerskie!”. „Wstyd w Sejmie” - demonstracja poparcia związków partnerskich, 27.01.2013, http://wiadomosci.gazeta.pl/ wiadomosci/1,114873,13304251,_Wstyd_w_Sejmie_demonstracja_poparcia_zwiazkow.html [dostęp: 22.03.2014]. 
Takiego poparcia udzielały również obecne na demonstracji rodziny z dziećmi ${ }^{24}$. Jej uczestników poproszono później na łamach „Przekroju” o odpowiedź na kilka pytań w artykule zatytułowanym Mamo, tato, co to jest związek partnerski?. Zbiór wypowiedzi zgromadzonych wśród osób wykonujących wolne zawody i prywatnych przedsiębiorców charakteryzował się dosyć spójnym przekazem dotyczącym nowoczesnego modelu obywatelstwa, który przewiduje zaangażowanie polityczne, partnerstwo rozumiane jako codzienną współpracę pomiędzy członkami rodziny (również tej poszerzonej), tolerancję dla odmienności i alternatywnych stylów życia oraz edukację promującą postawy obywatelskie, udostępniając tym samym związkom partnerskim dużą przestrzeń w nowoczesnej konstrukcji polskości opartej na modelu społeczeństwa obywatelskiego. Co znamienne, „związek partnerski" pojawia się w artykule tylko raz: w tytule. Partnerstwo przedstawione jest jako pożądana postawa obywatelska młodych rodziców (wypowiadają się mieszkańcy Warszawy, o względnie stabilnej sytuacji materialnej i funkcjonujący zawodowo na wolnym rynku). Postawy tej - będącej składową nowoczesnego patriotyzmu - dzieci uczą się zarówno chadzając z rodzicami pod Sejm na demonstrację popierającą ustawę o związkach partnerskich, jak i zakładając wraz z kolegami ze szkoły uczniowską bibliotekę z książek, które trafiają na śmietniki, a także przygotowując z bratem i tatą domowe wypieki (wyręczając mamę, przypisaną do tego zadania na mocy tradycyjnego podziału ról między mężem i żoną).

Nie bez znaczenia jest tutaj uwaga, że osoby udzielające w przytoczonym artykule poparcia dla związków partnerskich są aktywnymi na wolnym rynku przedsiębiorcami - własnymi pracodawcami, regulującymi czas i sposób wykonywanej przez siebie pracy ${ }^{25}$. W innych artykułach ${ }^{26}$, które pojawiły się na portalach internetowych związanych z gospodarką i biznesem wskazuje się na przykład, że deweloperzy zajmujący się sprzedażą mieszkań czy banki udzielające na te mieszkania kredytów nie stwarzają partnerom większych problemów przy wykonywaniu usług, które oferują swoim klientom ${ }^{27}$. Związki partnerskie są nawet utożsamiane z osobami, które - w czasach kryzysu ekonomicznego - stać na zakup własnego mieszkania. W kontekście trwającej od kilku lat dyskusji o tym, że coraz mniejsza liczba młodych ludzi może pozwolić sobie na zakup własnego mieszkania, bądź nie ma zdolności kredytowej wogóle, percepcja ta lokuje osoby homoseksualne wśród dobrze usytuowanych ekonomicznie przedstawicieli klasy średniej lub wyższej.

Postfordyzm (oparty na doktrynie neoliberalnej) - system produkcji i konsumpcji, w którym zaciera się wyraźna granica pomiędzy czasem pracy, czasem konsumpcji a czasem rekreacji i odpoczynku (Sennett 2007) - okazuje się być przestrzenią, w której osoby tworzące związki partnerskie mogą funkcjonować jako beneficjenci tego systemu, zarządzające sobą jednostki o dużych możliwościach

24 Jedna z kampanii społecznych zorganizowanych przez Internautów w odpowiedzi na argument przeciwników ustawy, jakoby legalizacja związków partnerskich miała zagrażać instytucji rodziny rozumianej jako małżeństwo kobiety i mężczyzny posiadających dzieci (był to też odzew na apel rodzin kaszubskich do premiera Donalda Tuska) była opatrzona hasłem "Związki partnerskie nie są dla nas zagrożeniem”. Kampania ta skupiała przede wszystkim małżeństwa z dziećmi. Zob. https://www.facebook.com/ZwiazkiPartnerskieNieSaDlaNasZagrozeniem?fref=ts [dostęp: 22.03.2014].

${ }^{25}$ Są to: architektka, dziennikarze, prywatni przedsiębiorcy, filmowiec, prawnik, których wykształcenie niekoniecznie pokrywa się z wykonywanym obecnie zawodem.

26 Zob. Dariusz Brzostek, Ta branża akceptuje związki partnerskie, 08.02.2013, http://biznes.onet.pl/ta-branza-akceptujezwiazki-partnerskie,18496,5416043,2,news-detal [dostęp: 22.03.2014].

27 W prezentacji badań ankietowych dotyczących sytuacji społecznej osób LGB w latach 2010-2011 czytamy, że "Niepokojenie przez sąsiadów było pięć razy częściej wybierane przez respondentów niż kłopoty z dzierżawą, wynajmem czy sprzedażą" (Abramowicz 2012:53). 
konsumpcyjnych, dzięki którym manifestują swoją tożsamość w oparciu o podejmowane decyzje, kupowane marki czy prowadzony styl życia (por. Woltersdorff 2007; Baudrillard 2001).

Wertując artykuły dotyczące debaty wokół związków partnerskich w Polsce, na dłuższą chwilę za-

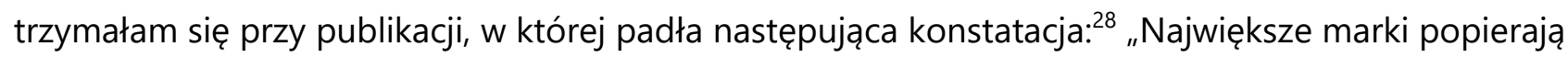
małżeństwa homoseksualne w USA. Takiego wsparcia zabrakło związkom partnerskim w Polsce?"

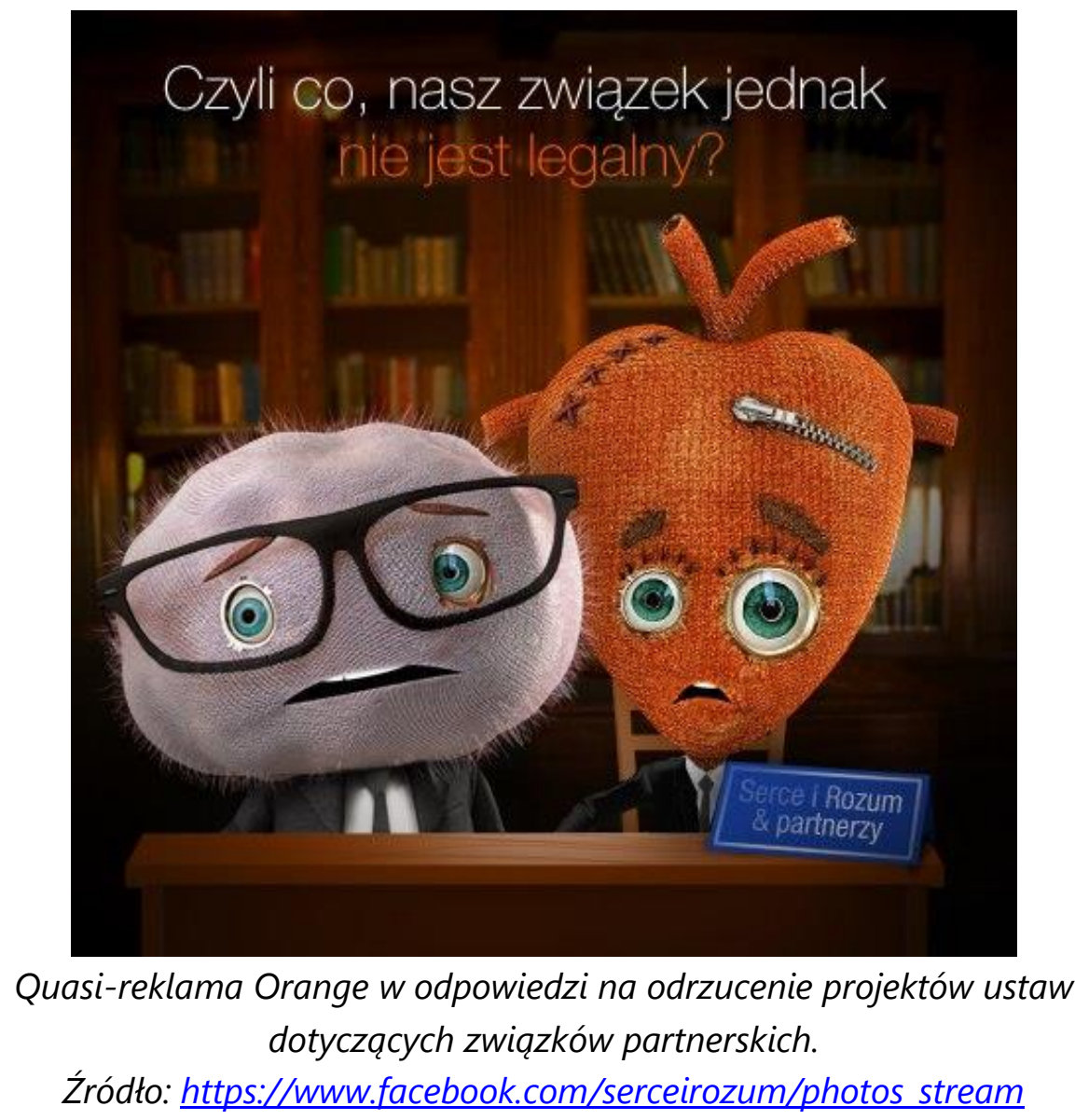

Leżąca u podstawy niniejszej pracy teza, że wolny rynek i neoliberalną wizję konsumeryzmu łączy silny związek z emancypacją seksualną, w tym wypadku - emancypacją wąsko rozumianej tożsamości homoseksualnej - była powodem, by pozostać przy artykule dłużej i zgłębić relację dyskursu rynkowego z sytuacją osób nieheteronormatywnych w Polsce i Stanach Zjednoczonych. Faktycznie, w polskiej debacie nad ustawą dotyczącą związków partnerskich nie uczestniczyły znaczące na polskim rynku marki i firmy. Jedynym wyjątkiem była quasi-reklama Orange (pochodząca z popularnego cyklu "Serce i Rozum") udostępniona na facebookowym fanpage'u². Nie doszukałam się

${ }^{28}$ Zob. http://natemat.pl/56331,najwieksze-marki-popieraja-malzenstwa-homoseksualne-w-usa-takiego-wsparcia-zabraklozwiazkom-partnerskim-w-polsce [dostęp: 4.05.2013].

29 Reklamy "Serce i Rozum" to jedna z pierwszych kampanii reklamowych odwołująca się do emocjonalnych, nie racjonalnych korzyści wynikających z podejmowania określonych decyzji konsumenckich przez jej odbiorców, na czym według specjalistów od reklamy polega jej ogromny sukces - to polski fanpage na facebooku, który zgromadził już ponad 2 miliony fanów i zajął pierwsze miejsce w rankingu popularności. 
jednak oficjalnego stanowiska firmy udzielającego poparcia związkom partnerskim ${ }^{30}$. W trakcie poszukiwań odnalazłam informację, że magazyn „F5"31 śledzący i wytyczający nowe trendy w branży kreatywnej również poszukiwał polskich marek, które udzieliły wsparcia związkom partnerskim, co sygnalizuje, jak wiele wspólnego ma gospodarka z kulturą. Analiza zjawisk społeczno-kulturowych pomijająca kwestie gospodarcze bazuje na założeniu, że kultura może funkcjonować w gospodarczej próżni, zaś na zmiany społeczne i praktyki kulturowe ludzi nie wpływa dynamiczny kontekst ekonomiczny. Sprzeciwiając się takiemu założeniu postaram się uzasadnić, że kwestie społecznokulturowe i gospodarcze działają na siebie na zasadzie sprzężenia zwrotnego.

\section{Emancypację przynosi wolny rynek? Dla kogo?}

Poszukiwania redakcji "F5" nawiązywały do kampanii prowadzonych przez przedstawicieli świata biznesu w ramach trwających w podobnym czasie w Stanach Zjednoczonych obrad Sądu Najwyższego wokół tzw. ustawy o obronie małżeństwa obowiązującej od 1996 roku (ang. Defense of Marriage Act, sprawa United States $v$. Windsor ${ }^{32}$ ) określającej małżeństwo - podobnie jak w Polsce - jako związek kobiety i mężczyzny ${ }^{33}$. Powodem, dla którego DOMA trafiła do Sądu Najwyższego, był zarzut o niekonstytucyjność aktu prawnego, który godzi w prawa człowieka: dyskryminuje osoby homoseksualne, odbierając legalnym małżeństwom jednopłciowym $1138^{34}$ praw, obowiązków i przywilejów federalnych przysługującym małżeństwom zdefiniowanym w DOMA jako związek kobiety i mężczyzny. Na wokandę trafiła również poprawka nr 8 (ang. Proposition 8; sprawa Hollingsworth $v$. Perry) do konstytucji stanu Kalifornia znosząca legalność małżeństw jednopłciowych, po tym jak zostały zalegalizowane w 2007 roku. Oficjalnego poparcia dla legalizacji małżeństw jednopłciowych w USA po raz pierwszy udzielił sprawujący urząd prezydent Stanów Zjednoczonych, Barack Obama, który w swojej mowie inaugurującej drugą kadencję podkreślił konieczność poszerzenia przestrzeni wolności i równości dla kolejnych dyskryminowanych grup społecznych, w tym osób homoseksualnych ${ }^{35}$.

30 Orange Polska jest sygnatariuszem Karty Różnorodności i było opiekunem dokumentu w 2013 roku. Inauguracja polskiej wersji Karty miała miejsce 14 lutego 2012 roku, zaś stworzenie dokumentu, który promuje „politykę równego traktowania ze względu na płeć [...], orientację psychoseksualną, tożsamość płciową, status rodzinny, styl życia" zainicjowało Forum Odpowiedzialnego Biznesu. Zob. http://kartaroznorodnosci.pl/pl [dostęp: 30.07.2014].

31 Magazyn zamieścił na swoim facebookowym profilu pytanie do Internautów brzmiące: „znacie jakieś polskie marki, które oficjalnie popierają związki homoseksualne?". Odpowiedzi użytkowników Facebooka wskazały zaledwie kilka niszowych firm, których targetem jest ściśle środowisko LGBT.

32 Sprawę zainaugurował problem z podatkiem od spadku po zmarłej żonie, który Edith Windsor musiała zapłacić (kwota ponad 350 tys. dolarów) w świetle obowiązującego prawa. Nie musiałaby ponosić tego rodzaju kosztów, gdyby była wdową po mężu.

33 Nie tylko prof. Ewa Łętowska przypominała w kontekście ubiegłorocznej debaty w Polsce, że ustawa zasadnicza nie rezerwuje instytucji małżeństwa tylko dla kobiety i mężczyzny. w podobnym tonie wypowiada się m.in. Mirosław Wyrzykowski, sędzia Trybunału Konstytucyjnego w stanie spoczynku, który podczas debaty wokół poprzedniego projektu ustawy o związkach partnerskich (2011 rok) wskazywał, że z Konstytucji wynika, że państwo jest w obowiązku uregulowania związków osób, które w świetle obowiązującego prawa nie mogą zawrzeć małżeństwa. Zob. http://wyborcza.pl/ 1,76842,10683837,Zwiazki partnerskie obowiazkowe.html [dostęp: 19.05.2014].

34 Human Rights Campaign (HRC; największa amerykańska organizacja walcząca o równe prawa osób LGBT) przygotowała przegląd najważniejszych z nich, zob. http://www.hrc.org/resources/entry/an-overview-of-federal-rights-and-protectionsgranted-to-married-couples [dostęp 22.03.2014].

35 Prezydent USA mówił: „Nasza podróż nie dobiegnie końca dopóty dopóki nasi bracia geje i siostry lesbijki nie będą traktowani w majestacie prawa tak samo jak ktokolwiek inny - jeśli rzeczywiście stworzono nas równymi, to miłość, którą siebie nawzajem otaczamy musi być tak samo równa". Zob. http://theweek.com/article/index/239044/obamas-secondinaugural-the-most-important-gay-rights-speech-ever [dostęp: 22.03.2014]. 
Jak pokazują statystyki ${ }^{36}$ firmy konsultingowej Gallup, która w 1996 r. po raz pierwszy badała opinię publiczną, pytając o tolerancję wobec małżeństw jednopłciowych, respondentów udzielających poparcia parom homoseksualnym było w 2013 roku dwukrotnie więcej niż 17 lat wcześniej, co stanowi $52 \%$ biorących udział w badaniu ${ }^{37}$. Medialne ocieplenie wizerunku osób LGBT dzięki takim produkcjom telewizyjnym jak "The New Normal” czy "Modern Family"38 ukazującym ich zwykłe życie, niewiele różniące się od tego wiedzionego przez małżeństwa heteroseksualne, rola nowych mediów jako alternatywnego kanału komunikacji i tworzenia reprezentacji rzeczywistości (Rams 2011) czy coraz częstsze "wyjścia z szafy” (coming out) celebrytów, z pewnością wpłynęły na rosnące poparcie dla małżeństw jednopłciowych, czego znamiennie dowodzi tempo, w jakim na przestrzeni kilku ostatnich lat kolejne stany umożliwiały zawieranie takich małżeństw ${ }^{39}$, w wielu przypadkach ustanawiając nowe prawo na mocy publicznych referendów.

W Stanach Zjednoczonych prywatni pracodawcy i rynkowi giganci zrzeszeni w zainicjowanej przez Human Rights Campaign (HRC) Business Coalition for DOMA Repeal (Koalicja świata biznesu na rzecz uchylenia DOMA ${ }^{40}$ jednoznacznie opowiedzieli się za zagwarantowaniem małżeństwom jednopłciowym identycznych praw, przywilejów i obowiązków zastrzeżonych dotychczas dla małżeństw dwupłciowych. Dwa ważne orzeczenia ogłoszone 26 czerwca 2013 roku przez Sąd Najwyższy, z których jedno zrównuje prawa, obowiązki i przywileje małżeństw jednopłciowych i dwupłciowych na szczeblu federalnym w stanach, które zalegalizowały małżeństwa jednopłciowe, zaś drugie na powrót legalizuje takie małżeństwa w stanie Kalifornia, były poparte ważnymi dokumentami wpływającymi na judykaturę: tzw. opiniami przyjaciela sądu, podpisanymi m.in. przez biznesową koali$\mathrm{cję}^{41}$. Są to opinie prawne przesyłane do sądu jako dodatkowy argument w sprawach najczęściej dotyczących kontrowersyjnych dla opinii publicznej tematów. Odpowiedź na pytanie, które w 2008 roku zadała w kwestii zrównania w świetle prawa małżeństw jedno- i dwupłciowych Linda L. Barkacs z Uniwersytetu w San Diego: Kiedy społeczeństwo nadąży za światem biznesu? (Barkacs 2008) mogłaby brzmieć: 26 czerwca 2013 roku, choć żadna z decyzji nie wprowadza małżeństw jednopłciowych na całym terytorium USA. Niemniej, orzecznictwo sądu nie jest reperzentatywne dla postawy całego społeczeństwa, choć można by pokusić się o stwierdzenie, że stosunek w głosowaniu sę-

36 Z wszystkimi przeprowadzonymi w 2013 roku ankietami dotyczącymi praw małżeństw jednopłciowych można zapoznać się na stronie http://www.pollingreport.com/civil.htm [dostęp: 22.03.2014].

${ }^{37}$ Gallup dwukrotnie (w trakcie procesów i po ich zakończeniu) pytał mieszkańców Stanów Zjednoczonych o poparcie dla legalizacji małżeństw jednopłciowych na szczeblu federalnym. Zob. http://www.gallup.com/poll/162398/sex-marriagesupport-solidifies-above.aspx oraz http://www.gallup.com/poll/163730/back-law-legalize-gay-marriage-states.aspx [dostęp: 22.03.2014].

38 Serial „Modern Family" podejmuje problematykę rekonstrukcji wąsko rozumianego modelu rodziny i dynamiki związków międzyludzkich. Pokazuje, że nie tylko związki homoseksualne są jednym z funkcjonujących w amerykańskim społeczeństwie konfiguracjami rodziny, lecz również życie par i osób heteroseksualnych podlega ciągłym przeobrażeniom, wymykając się konserwatywnemu rozumieniu tego, czym jest rodzina.

39 Po tym, jak Massachusets zalegalizowało małżeństwa jednopłciowe w 2004 roku, stając się taką szóstą jurysdykcją na świecie, minęły 4 lata, gdy stan California rozpoczął "falę" legalizowania małżeństw tej samej płci. Jak dotąd najwięcej stanów (bo aż 7) umożliwiło zawieranie takich związków w 2013 roku. Nie bez znaczenia było tu orzecznictwo Amerykańskiego Sądu Najwyższego w dwóch toczących się sprawach i prowadzone kampanie społeczne.

${ }^{40}$ Zob. http://www.hrc.org/laws-and-legislation/federal-legislation/respect-for-marriage-act [dostęp: 4.05.2013].

41 Prawnicy Edith Windsor celowo zabiegali o opinie „przyjaciela sądu” wśród społeczności biznesowej, chcąc otrzymać poparcie od "nietypowych świadków” w sprawie. Jedną z prawniczek, Robertę Kaplan, dochodziły w kuluarach podpowiedzi, by "zdehomoseksualizować" (to de-gay) sprawę. Zob. Ariel Levy, The Perfect Wife. How Edith Windsor Won a Landmark Case for Gay Marriage, "New Yorker”, 30.09.2013; http://www.newyorker.com/reporting/2013/09/30/130930fa fact levy [dostęp: 22.03.2014] 
dziów (5:4) odzwierciedlał wspomniane wyżej dane statystyczne opublikowane przez Gallup tuż po wydaniu orzeczenia.

Należy podkreślić, że sprawa Windsor dotyczyła tylko 3. sekcji DOMA odmawiającej legalnie zawartym małżeństwom jednopłciowym szeregu praw i przywilejów zagwarantowanych na szczeblu federalnym, natomiast sekcja 2. ustawy wciąż zachowuje swą ważność: to poszczególne stany decydują o tym, czy na ich obszarze małżeństwa takie są legalne czy nie. Wynika to z konstytucji USA, zgodnie z którą prawo do udzielania małżeństw przysługuje władzom stanowym. Oznacza to, że pary, które wzięły ślub w stanie im to umożliwiającym, w przypadku przeprowadzki do stanu zakazującego małżeństw jednopłciowych, mogą utracić nabyte prawa ${ }^{42}$.

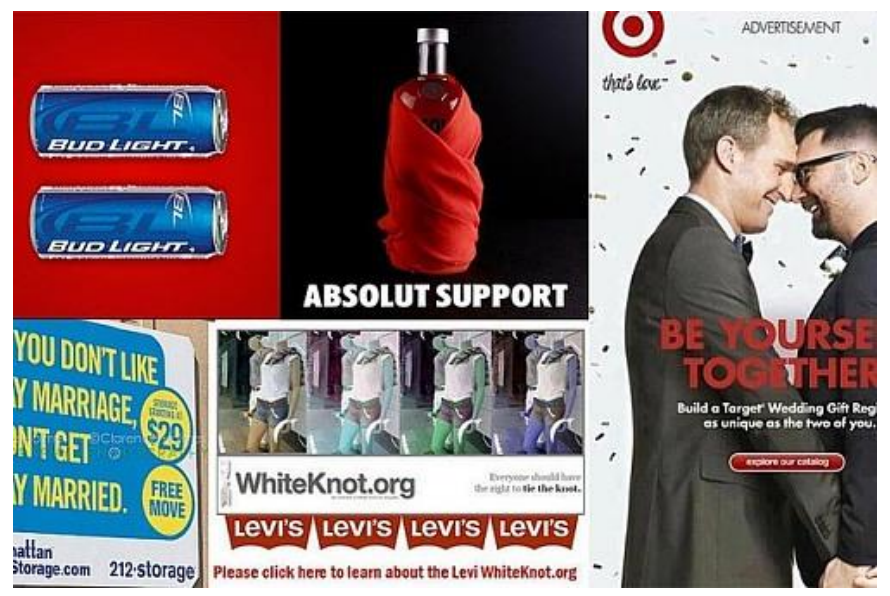

Marki wspierające małżeństwa jednoptciowe w USA.

Źródto: http://natemat.pl/56331,najwiekszemarki-popieraja-malzenstwa-homoseksualnew-usa-takiego-wsparcia-zabraklo-zwiazkompartnerskim-w-polsce

W opinii „przyjaciela sądu” koalicja amerykańskich pracodawców konstruuje narrację popierającą małżeństwa jednopłciowe wokół poszanowania różnorodności swoich pracowników oraz obecnej dyskryminacji, jakiej doświadczają, nie mogąc korzystać z praw i przywilejów pracowniczych zastrzeżonych dla małżeństw heteroseksualnych. Ponadto, koalicja wykazuje, że DOMA przyczynia się również do strat finansowych, jakie ponoszą pracodawcy (w świetle obowiązującego prawa niektórzy z nich - Ernst \& Young, Facebook, Google - wprowadzili np. praktykę "ubruttowiania”, czyli grossing up, polegającą na zawyżaniu dochodu pracowników, by mogli oni otrzymać taką samą stawkę, jak ich heteroseksualni współpracownicy, lub zwracania kosztów za nieprzysługujące dotychczas homoseksualnym pracownikom przywileje socjalne). Pary homoseksualne występują tu w charakterze dyskryminowanych podmiotów, ofiar pozbawionych przez państwo sprawczości i wpływu na swoje funkcjonowanie, zaś firmy - prywatni pracodawcy - to strona szanująca odmienność, różne style życia pracowników i wyznawane przez nich wartości.

42 Choć decyzja Sądu Najwyższego z 26 czerwca 2013 roku jest przełomowa, to rodzi dla par homoseksualnych szereg prawnych przeszkód. Nie od razu bowiem prawo zostało wprowadzone w życie, zaś każdorazowo, stan może brać pod uwagę inne kryterium w przyznawaniu małżeństwom praw i przywilejów federalnych - w zależności od tego, gdzie związek był zalegalizowany (place of celebration), bądź od tego, gdzie para mieszka w danym momencie (place of residence). HRC we współpracy z innymi organizacjami wspierającymi osoby LGBT pracują nad informatyzacją bezpośrednio zainteresowanych zmianami osób. Zob. http://www.hrc.org/blog/entry/what-do-the-doma-decisions-mean-for-you. w Kongresie czeka natomiast projekt ustawy Respect For Marriage Act (ustawa poszanowania małżeństwa) znoszącej całość zapisów w DOMA, nie wpływającej jednak na prawo poszczególnych stanów do stanowienia o (nie)legalności małżeństw jednopłciowych. 
Państwo wypada w tym zestawieniu kiepsko: uprzywilejowując określoną organizację seksualności zakorzenioną w rodzącej się pod koniec XVIII wieku biopolityce, mającej na celu "produkcję" wydajnych i zdrowych jednostek wspierających rozwój kapitalizmu (Foucault 1995: 123; D'Emilio 1983: 469-470), zaczyna być - jako zewnętrzna struktura - opresyjna dla jednostek niewpisujących się w promowany model seksualnego obywatelstwa (Weeks 1998). W tym samym czasie świat biznesu kreuje zupełnie odmienny wizerunek małżeństw jednopłciowych, głosząc tezę: „małżeństwo jednopłciowe może być dla niektórych rewolucją, ale dla amerykańskich przedsiębiorców, to tak naprawdę ewolucja" (tłum. aut.) $)^{43}$.

Jak donosi ubiegłoroczny raport HRC (Corporate Equality...), wiele firm, członków Koalicji świata biznesu na rzecz uchylenia DOMA, w tym duża część z listy Fortune 500 - rankingu amerykańskich firm klasyfikowanych według generowanego dochodu - zapewnia swoim pracownikom LGBT systemy opieki zdrowotnej, ubezpieczenie społeczne czy emeryturę na innych zasadach niż małżeństwom heteroseksualnym. To pracodawca, nie państwo, jest opiekunem ${ }^{44}$ dbającym o morale homoseksualnych pracowników, gdyż jak dowiadujemy się z amicus curiae brief (Brief of 278...):

Jako „przyjaciele sądu” jesteśmy pracodawcami lub stowarzyszeniami pracodawców, dzielącymi chęć przyciągnięcia, zatrzymania i zabezpieczenia utalentowanych pracowników [...]. Jednocześnie, jesteśmy stroną, na którą 3. sekcja ustawy o obronie małżeństwa („DOMA”) ma wpływ, nie rozpoznając małżeństw jednopłciowych na szczeblu federalnym. Ten dualny reżim nakłada obciążenie na "przyjaciół sądu". Wystawia nas, pracodawców, na zbyteczne koszty i chaos administracyjny, i bez względu na prowadzony przez nas biznes oraz profesjonalne orzecznictwo, zmusza nas do traktowania jednej grupy naszych legalnie połączonych węzłem małżeńskim pracowników inaczej niż pozostałych, podczas gdy nasz sukces uzależniony jest od dobrobytu i morale wszystkich zatrudnionych (tłum. aut.).

Pośród sygnatariuszy znajdziemy niemalże wszystkie wiodące na rynku - zarówno amerykańskim, jak i globalnym - firmy działające w branży IT i nowych mediach. Poparcia dla małżeństw jednopłciowych udzielają m.in.: Adobe Systems, Amazon, Apple, eBay, Electronic Arts, Facebook, Google, Intel, Microsoft, Twitter, a zatem te firmy, które niemalże zmonopolizowały i zdeterminowały sposób komunikacji i funkcjonowania najmłodszej grupy konsumentów w silnie zurbanizowanych i zaawansowanych technologicznie ośrodkach. Wiele z tych firm na dowód poparcia wzięło udział w marcowej, kilkudniowej kampanii HRC, gdy miało miejsce pierwsze czytanie w sprawie United States $v$. Windsor, udostępniając na swoich profilach na Facebooku i Twitterze dopasowane do własnej marki różowo-czerwone logo HRC. Niektóre firmy poszły o krok dalej. Zanim przejdę do finalnej linii

43 Oryg.: Same-sex marriage may seem revolutionary, but for American business, the idea truly is evolutionary. Gates G., Witeck B. Same-sex Marriage. What's at stake for Business? Urban Institute, 2004. Zob. http://www.urban.org/ publications/900722.html [dostęp:22.09.2013].

${ }_{44}$ Należy pamiętać, że od lat 70., wraz z propagowaniem doktryny neoliberalnej (monetaryzm) przez Miltona Friedmana system państwa opiekuńczego (doktryna interwencjonizmu państwowego Johna Maynarda Keynesa) zaczął być stopniowo rozmontowywany i w tym momencie w USA to pracodawca zapewnia pracownikom szereg przywilejów socjalnych (employee benefits), zaś państwo odgrywa tu rolę uzupełniającą. 
argumentacji niniejszego artykułu, poddam analizie dwie reklamy opublikowane przez Microsoft ${ }^{45}$ i Amazon ${ }^{46}$.

Biorące udział w reklamie Amazona postaci to młodzi, biali Amerykanie mogący pozwolić sobie na zakup czytnika e-booków Kindle Paperwhite, a nawet wymianę starszego brata produktu (uniemożliwiającego czytanie e-booków w pełnym słońcu) na nowszy, w kilka sekund po sugestii używającej go klientki. Bohaterów reklamy - kobietę i mężczyznę - stać również na urlop w kurorcie wypoczynkowym nad brzegiem oceanu stanowiącego scenerię reklamy.

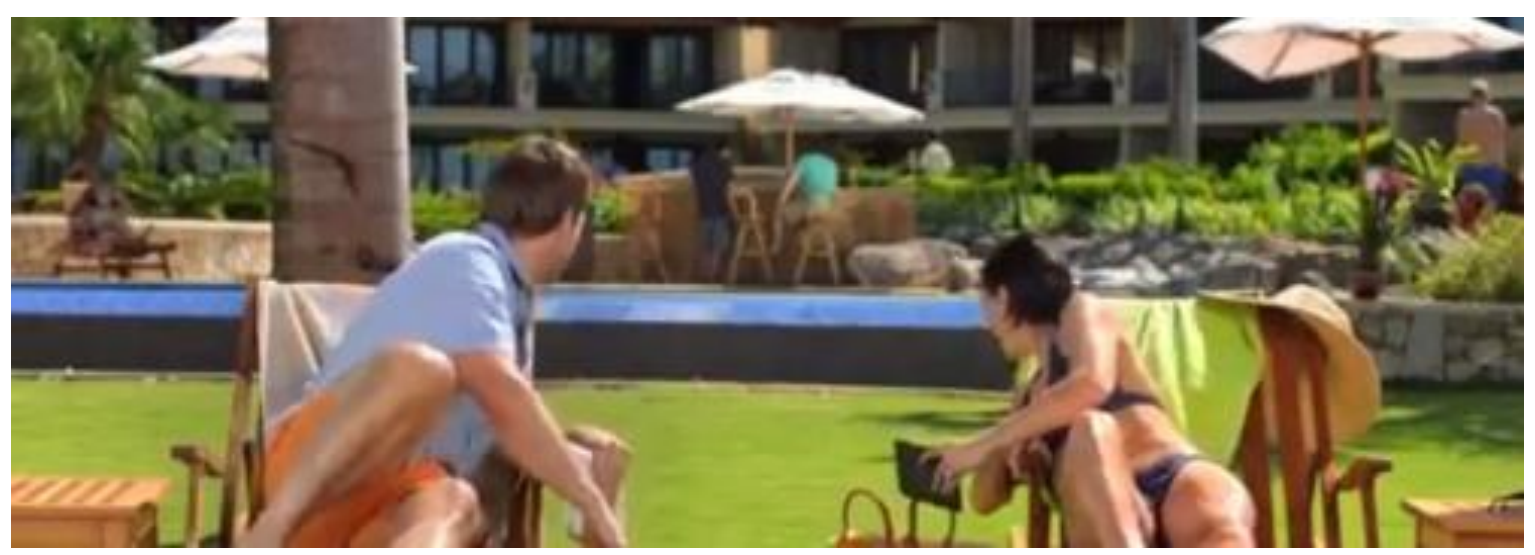

Jak sugeruje tytuł, Amazon Kindle Paperwhite doskonale nadaje się na plażę (Is Perfect at the Beach), gdzie zakup nowego czytnika Kindle należy uczcić drinkiem. Okazuje się, że bohaterowie czekają, aż przyniosą im je ich mężowie. Dla obu par sąsiedztwo małżeństwa homoseksualnego i heteroseksualnego stanowi normę, na ich twarzach ani przez moment nie rysuje się zdziwienie czy dyskomfort.

Reklama Microsoftu idzie nieco dalej. Ponownie, postaci w niej występujące to biali Amerykanie doskonale poruszający się w świecie zaawansowanych technologii, a przede wszystkim (reklamowanym produktem jest nowa wersja poczty Outlook) pozostający w nieustannym kontakcie ze swoimi znajomymi dzięki błyskawicznym aktualizacjom internetowym przypominającym w zakresie funkcjonowania facebookową "ścianę" (wall), na której użytkownicy zamieszczają nowinki ze swojego życia (najnowsza wersja Outlooka umożliwia migrację aktualizacji zamieszczanych przez użytkowników na portalach Facebook, Twitter i LinkedIn). Hasło reklamowe brzmi: „Bądź na czasie” (Get up to date).

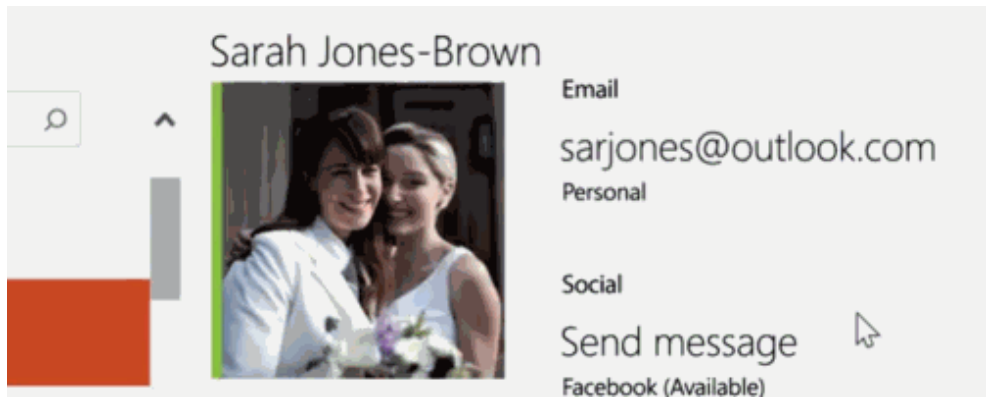

${ }^{45}$ Zob. https://www.youtube.com/watch?v=IS3t9reE364 [dostęp: 22.03.2014].

${ }^{46}$ Zob. https://www.youtube.com/watch?v=TdXxNBxWcVE [dostęp: 22.03.2014]. 
Mężczyzna debiutuje w swojej nowej pracy (przestaje być dostawcą, by zostać kaskaderem); po brawurowym spowodowaniu odgrywanego wypadku samochodowego od razu obwieszcza znajomym dzięki nowej usłudze Outlook swoją nową profesję. Para lesbijek bierze ślub i momentalnie nazwisko jednej z nich przestaje być jednoczłonowe, zaś na zdjęciu profilowym znajduje się teraz fotografia nowożeńczyń. Wszystko śledzi, nie odchodząc od swego komputera, wspólna znajoma mężczyzny i kobiet, która zaraz po odczytaniu towarzyskich nowinek gratuluje im, komentując wszystko na swoim Outlookowym profilu.

Microsoft pokazuje rzeczywistość, w której zarówno diametralna zmiana charakteru wykonywanej pracy, jak i małżeństwa homoseksualne nie stanowią odchylenia od normy, a przepływ informacji między ludźmi odbywa się głównie za pośrednictwem Internetu. „Bycie na czasie” oznacza również akceptację różnych stylów życia, w tym innej niż heteroseksualna orientacji. Reklama mieści w sobie niemalże cały wachlarz elementów składowych doktryny neoliberalnej: uczenie się przez całe życie, elastyczność na rynku pracy, tolerancję dla różnorodności, mobilność ${ }^{47}$, ale generuje też przekaz o tym, kto jest uczestnikiem tej rzeczywistości, uchwytując dynamikę podziałów klasowych. Osoby homoseksualne są tu sportretowane jako uczestnicy miejskiej kultury białej klasy średniej, gdzie emancypacja mierzona jest stopniem uczestnictwa w usługach i możliwością nabycia dóbr oferowanych w systemie kapitalistycznym dla tych, których stać na to, by za nie zapłacić (zob. Majka 2010). Ponownie mamy do czynienia z wykluczającym homonormatywnym modelem: czy Afroamerykanin z klasy robotniczej mieszkający w małym miasteczku nie może identyfikować się jako osoba homoseksualna?

Warto zauważyć, że utwór wykorzystany w reklamie - "Can't Hold Us" - wykonywany jest przez duet rapersko-producencki z Seattle, Macklemore \& Ryan Lewis ${ }^{48}$, który jest silnie zaangażowany we wspieranie małżeństw jednopłciowych. Sukces - w Stanach Zjednoczonych i o zasięgu globalnym - osiągnęli w 2012 roku dzięki premierze albumu "The Heist", na którym pojawił się utwór „Same Love"49, poruszający kwestię homoseksualności i homofobii. Opowiadając o własnych doświadczeniach z homoseksualizmem, Macklemore stwierdza, że gdyby był gejem, świat hip-hopu najpewniej by go znienawidził. Nagranie szybko stało się viralem, swoistym "hymnem" milionów młodych ludzi w USA popierających małżeństwa jednopłciowe, i obudziło dyskusję wokół homofobicznych postaw pośród raperów, co zbiegło się w czasie z „wyjściem z szafy” kilku wykonawców

47 Należy rozróżnić lewicowe i neoliberalne rozumienie "uczenia się przez całe życie” i powiązanych z nim - wymienionych powyżej - składowych, które we współczesnym kapitalizmie tworzą spójną całość. o ile lewicowe, powiązane z etosem inteligencji kształcenie ustawiczne dotyczy samodoskonalenia i zdobywania wiedzy oraz umiejętności wzbogacających osobowość człowieka per se jak i w służbie społeczeństwu, tak neoliberalna koncepcja uczenia się przez całe życie jest łącznikiem pomiędzy edukacją dorosłych, a przygotowaniem mobilnych, adaptujących się do zmiennych kontekstów społeczno-kulturowych (tolerancja) i elastycznych jednostek dla zmiennej globalnej gospodarki rynkowej oraz wpisuje się w dyskurs wiedzy przynoszącej wymierne korzyści ekonomiczne („transfer wiedzy do gospodarki"). "Produkowani" w tej technologii edukacji pracownicy są wytworami rynkowej rządomyślności (Olssen 2008), za pomocą której obywatel definiowany jest jako "klient”, "konsument" odpowiedzialny za swoje wybory, a przez to własne umiejscowienie społeczne i ekonomiczne, zaś samo uczenie się jest w tutaj rozumiane jako nieustanne dodawanie kompetencji i umiejętności odpowiadających na zmienne warunki zatrudnienia i rozwój technologiczny.

48 Muzycy stali się niemalże ikoną kampanii na rzecz tolerancji dla małżeństw jednopłciowych. Ich inny utwór "And We Dance" został wykorzystany w reklamie firmy odzieżowej Nordstrom wspierającej pary homoseksualne.

49 Zob. http://www.youtube.com/watch?v=hIVBg7 08n0; utwór ma już ponad 113 milionów wyświetleń na YouTube [dostęp: 24.03.2014] 
młodszej generacji związanych ze światem hip-hopu (Frank Ocean, Angel Haze, Azealia Banks) czy swobodniejszego udzielenia aprobaty dla homoseksualistów przez innych (A \$AP Rocky, Murs, JayZ, Eminem, 50 Cent, T.I.) ${ }^{50}$. Znamienne, że podczas gdy oswajające z małżeństwami jednopłciowymi reklamy wielkich marek ilustrują wchodzące w takie związki osoby jako przedstawicieli dobrze usytuowanej białej klasy średniej, otaczających się nowinkami technologicznymi i będącymi zawsze na czasie z panującymi trendami, kultura hip-hop (uznawana za jedną z najbardziej homofobicznych i konserwatywnych w kwestii ról genderowych) okazuje się przestrzenią emancypacji osób homoseksualnych, dla których zabrakło miejsca w dyskursie rynkowym, a przynależących do młodszej części społeczeństwa, a także innych grup społecznych ${ }^{51}$.

Zarówno w Polsce, jak i w Stanach Zjednoczonych dyskusja i uwaga mediów wokół praw osób homoseksualnych pomija problematykę klasową. Z opublikowanych w 2005 roku badań socjologicznych przeprowadzonych w czterech największych amerykańskich miastach wynikało, że przynależność do niższej klasy społecznej i zamieszkanie poza tzw. gejowskimi dzielnicami (gay ghetto) wiąże się z mniejszym prawdopodobieństwem, by homoseksualni mężczyźni określali się jako "gej" i partycypowali w kulturze gejowskiej ${ }^{52}$, przypisując sobie homonormatywną tożsamość, która jest silnie sprzężona z zamożną, białą klasą średnią: nocnymi klubami, wolnymi zawodami i nieregulowanym czasem pracy (Barrett \& Pollack 2005: 451) ${ }^{53}$.

Można szukać tu potwierdzenia dla tezy postawionej w 1983 roku przez Johna D'Emilio, który pisał, że pojawienie się tożsamości homoseksualnej było uwarunkowane rozwojem kapitalizmu wymuszającego migrację kobiet i mężczyzn do miast ${ }^{54}$. Ludzie ci, opuszczając wsie i mniejsze miejscowości, zrywali też z tradycyjnymi rolami genderowymi oraz wzajemnym uzależnieniem swego przetrwania od płci przeciwnej (D'Emilio 1983). Ze zjawiskiem wiązała się również ważna zmiana w dominującym jeszcze w XVIII wieku modelu rodziny, który współcześnie bardziej konserwatywne i prawicowe grupy społeczne wciąż uznają za "właściwy" i "naturalny". Przeważający w medialnych przedstawieniach obraz tożsamości homoseksualnej deformuje społeczną rzeczywistość, sprawiając, że osoby homoseksualne o odmiennym usytuowaniu społeczno-ekonomicznym i nieidentyfikujące się z tą tożsa-

50 Mesfin Fekadu, Hip-Hop's Anti-Gay Tone Shifting After Frank Ocean's Coming Out, 23.08.2012 Zob. http://www.huffingtonpost.com/2012/08/23/hip-hops-anti-gay-tone-frank-ocean n 1824494.html [dostęp: 22.03.2014].

51 Podkreślę, że kultura hip-hop wywodząca się z amerykańskich gett i slumsów, kontestująca uprzywilejowane klasy społeczne i krytykująca dyskryminację Afroamerykanów, charakteryzuje się jednocześnie sztywnymi rolami genderowymi, gdzie mężczyzna najczęściej spełnia stereotyp silnego macho, zaś uległa, słaba kobieta pozbawiona jest sprawczości. Problemowi przyjrzał się m.in. Byron Hurt, twórca dokumentu Hip-Hop: Beyond Beats and Rhymes (2006).

52 Barrett i Pollack określają kulturę gejowską jako bliską modelowi homonormatywności, gdzie geje utożsamiani są z mieszkającymi w dużych miastach, aktywnymi konsumentami podążającymi za nowinkami technologicznymi, pracującymi w wolnych zawodach lub przedstawicielami „białych kołnierzyków”. Śledząc przejawy kultury gejowskiej w Polsce Majka-Rostek zaobserwowała, że po 1989 roku homoseksualność w dyskursie publicznym zaczęła być reprezentowana w medialnej figurze "idealnego geja”, mającej związek właśnie z wąsko rozumianą kulturą gejowską (Majka-Rostek: 2010).

53 Doskonałą analizę tej zależności mogliśmy prześledzić choćby we francuskim filmie "Życie Adeli” (2013), w którym homoseksualna para głównych bohaterek pochodzi z różnych klas społecznych.

54 D’Emilio zauważa, że mężczyźni częściej odkrywali swoją homoseksualną tożsamość funkcjonując w sferze publicznej i piastując zawody przynoszące im duże dochody, podczas gdy kobiety, choć zmieniając miejsce zamieszkania ze wsi na miasto, wciąż były uzależnione finansowo od mężczyzn. Współcześnie tę zależność możemy obserwować w wielu przypadkach, chociażby biorąc pod uwagę trwającą dyskusję dotyczącą niższych zarobków dla kobiet piastujących te same, co mężczyźni stanowiska, czy feminizację ubóstwa. z pionierskich w Polsce badań wynika, że lesbijki i kobiety biseksualne mieszające poza metropoliami często narażone są nie tylko na wykluczenie społeczne, lecz także gorszą sytuację ekonomiczną (Struzik 2012). 
mością podejmują strategię skrywania swej orientacji seksualnej, nieakceptowanej w tradycyjnej społeczności o sztywnych rolach kulturowych przypisywanych kobiecie i mężczyźnie, gdzie wyjście poza heteronormatywną matrycę może wiązać się z wykluczeniem społecznym i doświadczaniem przemocy (zob. Abramowicz 2012, Struzik 2012).

Głosy „za” małżeństwami jednopłciowymi w USA mają wiele punktów wspólnych z linią argumentacji popierającą związki partnerskie w Polsce. Z jednej strony dopatrzyć się możemy wizerunku osób wyłamujących się ze schematu heteronormatywnej rodziny tworzonej przez małżeństwo kobiety i mężczyzny. Osoby niepodążające za tradycyjnymi rolami przypisywanymi kobiecie i mężczyźnie przedstawiane są jako poszkodowane, doświadczające dyskryminacji ze względu na orientację seksualną. W konsekwencji, są one pozbawione praw i obowiązków wynikających z zawarcia małżeństwa (USA) czy w ogóle sformalizowania swego związku (Polska). Stanowiąc mniejszość, nie są beneficjentami opieki gwarantowanej przez państwo. Ludzie wyłamujący się z heteromatrycy, geje i lesbijki, zdani są na samych siebie i zatrudniających ich pracodawców, muszą wykorzystywać luki prawne i dopasować swój styl życia do normy obyczajowej i światopoglądowej wyznaczanej przez państwowe prawodawstwo. Z drugiej strony przedstawiani są jako zaradne podmioty przynależące do zamożnej klasy średniej mieszkającej w miastach, odnoszące sukces ekonomiczny i towarzyski, budujące swoją tożsamość w oparciu o świadomie dokonywane wybory - tyczą się one zarówno orientacji seksualnej, jak mobilności zawodowej czy konsumowanych produktów i usług.

\section{Miasto, klasa, kreatywność}

Wróćmy do wspierającego homoseksualnych pracowników i konsumentów świata biznesu z koalicji na rzecz uchylenia DOMA. W utartym rozumieniu, podstawowym celem prywatnych przedsiębiorców jest przede wszystkim kumulacja zysków i generowanie przychodu, między innymi poprzez poszerzanie grupy konsumentów gotowych zapłacić za produkt, sprzedawany przez firmę. Jakie korzyści czerpią firmy lobbując w tak kontrowersyjnej sprawie jak redefinicja małżeństwa? Czy masowe wręcz w przypadku USA udzielenie poparcia małżeństwom osób homoseksualnych przez świat biznesu potwierdza przesunięcie akcentu z ekonomicznej racjonalności związanej z heteroseksualną matrycą w kierunku prowadzenia przedsiębiorstw z poszanowaniem różnorodności pracowników i konsumentów jako rodzaj „ewolucji” wynikającej z dynamiki relacji międzyludzkich?

Przejście z liberalnego do neoliberalnego modelu gospodarczego oznaczało ważną jakościową zmianę w systemie produkcji i rozwoju gospodarczym. Akcent nie pada już na klasyczne czynniki sprzyjające biznesowi (takie jak dostępność surowca, lokalizacja, kapitał finansowy), lecz na miękkie, płynne, które można ująć w kategorii kapitału społecznego i gospodarki opartej na wiedzy. Wyzwanie, z którym mierzą się teraz pracodawcy i przedsiębiorcy brzmi: jak zainteresować i zatrzymać pracowników, których wiedzy, umiejętności, talentu i kreatywności potrzebujemy? Jak pisali dekadę temu Gary J. Gates i Richard Florida różnorodność, tolerancja dla inności i otwartość na alternatywne style życie są współczesnymi czynnikami lokalizacji biznesu, a raczej czynnikami, dla których potencjalni pracownicy decydują się na podjęcie pracy w określonej lokalizacji (Gates, Florida 2003). 
Florida jest twórcą jednej z najpopularniejszych i najbardziej kontrowersyjnych teorii z zakresu zarządzania miastami i urbanistyki, dzięki której zrobił międzynarodową karierę, doradzając władzom postindustrialnych miast i miasteczek: jak uczynić ich miejscowości kreatywnymi ${ }^{55}$. W swojej opublikowanej w 2002 roku książce "Narodziny klasy kreatywnej" (Florida 2010) jako jeden z czynników wpływających na atrakcyjność miasta wskazuje Gay Index - swoisty papierek lakmusowy na tolerancję mieszkańców, która ma wpłynąć na otwartość miasta i tym samym inkluzyjność klasy kreatywnej, czemu wtóruje Gates (2009):

Jednym z argumentów jest to, że [możliwość zawarcia] małżeństwa skłoni niektóre pary jednopłciowe do przeprowadzki do danego stanu, w szczególności osoby młode, dobrze wykształcone - członków tak zwanej klasy kreatywnej - które są kluczowymi aktorami dla rozwoju ekonomicznego w postindustrialnej gospodarce (tłum. aut.).

Argumentacja Floridy i Gatesa jednoznacznie lokuje osoby nieheteronormatywne w ramach homonormatywności, a więc w kapitalistyczno-normatywnym porządku. Autorzy sugerują, że gej i lesbijka to zazwyczaj dobrze wykształceni, zamożni przedstawiciele miejskiej klasy średniej. Z tego punktu widzenia nie dziwi, że jednym z wielu czynników, które przed legalizacją małżeństw jednopłciowych poszczególne stany brały pod uwagę, był wpływ takiego posunięcia na lokalną gospodarkę oraz potencjalne zyski ekonomiczne dla stanowego budżetu. Niemalże wszystkie raporty na ten temat ${ }^{56}$ opublikował Instytut Williamsa (Szkoła Prawa Uniwersytetu Kalifornijskiego w Los Angeles), którego dyrektor i założyciel, Bradley Sears, w jednym z wywiadów ${ }^{57}$ zapytany o odważne i ryzykowne stanowisko wielu firm w kwestii poparcia udzielonego małżeństwom jednopłciowym stwierdził, że

[...] trzeba pamiętać, że korporacje muszą myśleć nie tylko o swoich klientach, ale także o pracownikach. Żeby przyciągnąć najlepszych kandydatów, trzeba mieć najlepszą politykę zatrudnienia. Niektóre z nich patrzą też na to w szerszej, historycznej perspektywie - chcą być "po właściwej stronie historii”. Wierzą w to, że młodsi konsumenci docenią to ryzyko, uznają jego podjęcie za moralnie nacechowany gest. Jest też kwestia silnego przywództwa. Dla przykładu, szef Starbucksa powiedział wprost - jeśli się nie zgadzacie z moim stanowiskiem - sprzedajcie akcje spółki. Myślę, że pokazuje to szerszą wizję i inny typ przywództwa, niż ten zorientowany jedynie na kalkulację zysków i strat.

Gdy Sears mówi w kontekście decyzji Howarda Schulza o nowym typie przywództwa w firmach, ma na myśli rolę, jaką jednostka może spełnić w przemianie społecznej. W długoterminowej perspektywie natomiast dbające o swoją wysoką pozycję firmy postąpiły - z perspektywy "zysków i strat" -

${ }^{55}$ Koncepcje Floridy spotkały się z dużą falą krytyki, bowiem nieprzemyślane i pochopne promowanie koncepcji przemysłu kreatywnego często wiąże się z ogromnymi problemami społeczno-ekonomicznymi, takimi jak segregacja ludności, gentryfikacja czy zwiększanie przepaści ekonomicznej między różnymi grupami społecznymi (zob. McCann 2007).

56 Dostępne są na stronie http://williamsinstitute.law.ucla.edu/category/research/economic-impact-reports [dostęp: 22.09.2013].

57 To jeszcze nie koniec tej historii, Kultura Liberalna nr 235 (28/2013) z 9 lipca 2013 r. 
bardzo racjonalnie, sygnalizując jednocześnie swoje światopoglądowe stanowisko. Analiza poparcia opinii publicznej dla małżeństw jednopłciowych z uwagi na wiek respondentów jasno pokazuje, że akceptacja osób LGBT jest wprost proporcjonalna do malejącego wieku respondentów. Aż 69\% osób w przedziale wiekowym 18-34, biorących udział w ankiecie przeprowadzonej przez Gallup, deklarowało akceptację dla legalizacji małżeństw jednopłciowych na szczeblu federalnym. To pozwala przewidywać, że niepełnoletni Amerykanie, a zatem przyszli pracownicy i konsumenci, są w jeszcze większym stopniu tolerancyjni wobec nieheteronormatywnej seksualności. Jak policzyli analitycy Facebooka na krótko przed ogłoszeniem werdyktu w sprawie dwóch precedensowych spraw toczących się w Sądzie Najwyższym, 70\% amerykańskich użytkowników tego serwisu społecznościowego ma znajomego o innej niż heteroseksualna orientacji ${ }^{58}$.

\section{Konflikt: lokalny opór wobec homonormatywności}

Jeffrey Weeks, autorytet w dziedzinie badań nad historią seksualności pisał, że

Istnieją raczej seksualności, a nie jedna seksualność. [...] Powinniśmy uświadomić sobie, że seksualności produkowane są w społeczeństwie w skomplikowany sposób. Wynikają z różnorodnych praktyk społecznych, nadających znaczenie ludzkim działaniom, ze społecznych definicji i samookreśleń, ze zmagań tych, którzy mają władzę definiowania i regulowania z tymi, którzy stawiają opór. Seksualność nie jest dana, jest produktem negocjacji, walki i ludzkiej sprawczości. (Weeks 2012: 30-31)

Z uwagi na wielość seksualności oraz na związek seksualności z różnymi relacjami społecznymi, tym bardziej niepokojące powinno być dla nas wąskie rozumienie homoseksualności w sposób homonormatywny, której obraz generowany przez media przypisuje homoseksualność bardzo wąskiej grupie osób, sportretowanej jako beneficjenci neoliberalnego kapitalizmu. Postulowana w tym przekazie sprawczość - atrakcyjna forma tworzenia siebie, czy zarządzania sobą - nie jest dostępna dla wszystkich. Jeśli medialny przekaz dotyczący osób homoseksualnych ogranicza się do pokazywania ich jako zamożnych przedstawicieli miejskiej klasy średniej lub wyższej (w polskim wydaniu: Serce i Rozum to "partnerzy", białe kołnierzyki, argumentacja obecna w prasie umiejscawia osoby homoseksualne w miastach i przypisuje im wyższą od przeciętnej kondycję ekonomiiczną), otaczających się dobrami i usługami dla wielu niedostępnymi, nie powinien dziwić fakt, że środowiska o innych wzorcach konsumpcyjnych, broniące narodowych wartości, "naturalnego" ładu społecznego, rodziny jako podstawy organizacji społecznej, mogą umiejscawiać się w opozycji do takiej reprezentacji homoseksualności i przez to nie akceptować jej. Seksualna emancypacja jako rodzaj moralnego zepsucia (niszczącego lub redefiniującego zreifikowane lokalne tradycje, w tym prymat nuklearnej rodziny heteronormatywnej) jest w tym świetle odczytywana jako składowa ekspansji zachodniego neoliberalizmu, przed którym obrońcy tradycji bronią swoje społeczeństwo ${ }^{59}$. Badania

${ }^{58}$ Facebook opublikował informację: „Blisko 70\% osób zarejestrowanych na Facebooku w Stanach Zjednoczonych ma wśród swoich znajomych osobę, która identyfikuje się na swoim profilu jako gej, lesbijka lub osoba biseksualna" (oryg.: Approximately $70 \%$ of people on Facebook in the U.S. are connected to a friend who has expressly identified themselves as gay, lesbian or bisexual on their timeline).

59 Osoby z mniejszych miejscowości często poszukują przestrzeni emancypacji, decydując się na emigrację do dużego miasta lub za granicę, co najdobitniej pokazuje, że homoseksualność wiązana jest z wielkomiejskim fenomenem, podczas 
niehetoronormatywnych kobiet (w tym lesbijek i kobiet biseksualnych), mieszkających we wsiach i mniejszych miejscowościach w Polsce, pokazują między innymi, że dla lokalnych społeczności osoby homoseksualne "nie istnieją" w tym sensie, że wiązane są z ośrodkami wielkich miast i osobami wiodącymi wielkomiejski styl życia; zgodnie z logiką "natury” nie mogą funkcjonować na wsi, często nie są wyobrażalne (Struzik 2012), pomimo, że osoby nieheteroseksualne mieszkają i dorastają na obszarach wiejskich ${ }^{60}$.

Co więcej, w pozamiejskich ośrodkach, gdzie stopień społecznej anonimowości jest o wiele niższy, orientacja seksualna wciąż warunkuje pozycję ekonomiczną. Osoby homoseksualne, które (z wyboru lub braku środków) nie partycypują w kulturze miejskiej homonormatywności, ale decydują się na "wyjście z szafy”, mogą zatem mierzyć się ze społecznym wykluczeniem i koniecznością migracji lub - przeciwnie - w przypadku braku możliwości bądź chęci przeniesienia się do miasta "są w niekorzystnej sytuacji nie tylko ze względu na strukturalne ograniczenia terenów wiejskich, ale także ze względu na brak zainteresowania i zorientowania w ich sytuacji ze strony osób działających w ruchu LGBT" (Struzik 2012: 50). Niekiedy ci, którzy próbują włączyć się do tej odgórnie produkowanej zurbanizowanej kultury homoseksualnej, napotykają szereg ekonomicznych, kulturowych i społecznych przeszkód wynikających z różnic klasowych, o czym pisał na przykład jeden ze współtwórców strony internetowej The New Gay, podważający wąsko rozumianą homonormatywność: "Tytuł tego posta »Dlaczego odrzucam kulturę gejowską" jest w zasadzie niewłaściwy. Nie odrzuciłem jej. Starałem się ją przyswoić [...]. Starałem się. Kultura gejowska odrzuciła mnie (tłum. aut.) ${ }^{61}$.

Badania CBOS-u opublikowane w lutym 2013 roku zdają się potwierdzać powyższe wnioski, choć wciąż brakuje w Polsce badań uchwytujących dynamikę klasową, zatrudnienie, czy miejsce zamieszkania w kontekście tolerancji dla osób homoseksualnych, a ostatnio - związków partnerskich. Choć ta rośnie w zestawieniu z badaniami z lat poprzednich, to wciąż osoby młode, o wyższym wykształceniu, wysokich zarobkach, nieuczestniczące w praktykach religijnych, o poglądach lewicowych i osobiście znające osoby homoseksualne, częściej odpowiadają twierdząco na pytanie o uznanie par jednopłciowych (CBOS 2010). Nie ulega wątpliwości, że pośród tych, którzy odpowiadają na to pytanie przecząco, a więc osób starszych, o gorszej sytuacji ekonomicznej, praktykujących religijnie i często o poglądach prawicowych, również żyją geje i lesbijki ${ }^{62}$, ale wąskie rozumienie tożsamości homoseksualnej przyczynia się do budowania społecznych fortyfikacji, pogłębiając rozwarstwienie społeczne i dystansowanie się wsi od miasta i vice versa. Krzywdzące jest ponadto etykietowanie i wytyczanie sztywnych granic pomiędzy osobami wierzącymi jako przeciwnymi grupom nieheteronormatywnym oraz niewierzącymi jako takie grupy częściej akceptującymi. Istnie-

gdy osoby nieheteronormatywne funkcjonują również poza metropoliami. Logika ta jest jednak domniemana. Autorzy badań ankietowych dotyczących sytuacji społecznej osób LGB w Polsce wskazują brak badań potwierdzających kierunki migracji osób nieheteronormatywnych, wydając jednocześnie rekomendację dla pogłębienia badań ukazujących rozkład zmiennych socjodemograficznych wśród osób LGB (takich jak miejsce zamieszkania, wykształcenie, zarobki) oraz ich mobilność przestrzenną z uwzględnieniem determinujących ją czynników (Abramowicz 2012: 21).

60 W 2011 roku sołtysem wsi Leśniewo został Marcin Nikrant, jawny gej, Kaszub od pokoleń. Zob. http://wyborcza.pl/ 1,76842,10086870,Soltys ma chlopaka.html [dostęp: 30.07.2014].

61 Zob. http://thenewgay.net/2009/04/why-i-reject-gay-culture.html [dostęp: 22.03.2014].

62 Oczywiście zdaję sobie sprawę, że sposób definiowania i określania relacji seksualnych i emocjonalnych z osobami tej samej płci nie musi iść w parze z przyjmowaniem tożsamości homoseksualnej. Terminów "gej" czy "lesbijka" nie używam zatem w celu narzucania terminów określających tożsamość seksualną: mogą być one zewnętrzne wobec autoidentyfikacji osób nieheteronormatywnych. 
nie inicjatyw religijnych dla osób homoseksualnych jest najlepszym dowodem na to, że wiara, religijność i orientacja seksualna nie są wobec siebie wykluczające. Od 2010 roku działa w Polsce ekumeniczna grupa osób LGBTQ „Wiara i Tęcza”63, istnieją również Zjednoczony Kościół Chrześcijański czy poznański Reformowany Kościół Katolicki, akceptujące osoby LGBT (Kościańska 2012b).

Jaka relacja łączy kreację niezależnych i wyzwolonych jednostek z logiką wolnorynkowego neoliberalizmu, który nie jest jedynie systemem gospodarczym wpływającym na deregulację, reprywatyzację i destrukcję państwa opiekuńczego (Giroux 2004), ale również specyficznym sposobem rządomyślności (governmentality) ${ }^{64}$, inkorporowaną techniką samozarządzania tworzącą nową koncepcję jednostki i jej sprawczości? Jak pokazuje Ilana Gershon (2011), neoliberalny podmiot to przede wszystkim jednostka utwierdzona w przekonaniu o nieskończoności roztaczających się przed nią możliwości, która zarządza swoimi wyborami, opierając się na wąsko rozumianej rynkowej racjonalności - w modelowym ujęciu, buduje swoją tożsamość w podobny sposób, jak buduje się przedsiębiorstwo: zestawiając zyski i straty związane z każdorazowo podejmowaną decyzją i samą siebie obarcza odpowiedzialnością za społeczne, geograficzne i ekonomiczne umiejscowienie (por. MajkaRostek 2009). Tym samym wizerunek osoby homonormatywnej, promowany przez firmy obecne na rynku, to typ osobowości pożądanej przez neoliberalny system. Leży tu nie tylko niebezpieczeństwo związane z wąskim rozumieniem homoseksualności jako homonormatywności, ale również z jej reifikacją jako wielkomiejskiego fenomenu zastrzeżonego dla zamożnych osób z wyższym wykształceniem.

Podsumowując, homonormatywność jako rodzaj odgórnego zarządzania wtłaczającego jednostki w globalną wspólnotę częstokroć stoi w opozycji wobec taktyk pojedynczych podmiotów pozwalających na emancypację i opór wobec dominującej lokalnie struktury społecznej i wzorców genderowych (Brown 2012: 1069). Sama homonormatywność może zatem z jednej strony "produkować" przedstawicieli globalnej i horyzontalnej wspólnoty wyobrażonej (Anderson 1997, Donham 2012 ${ }^{65}$ ), zaś z drugiej zmniejszać sprawczość jednostek nierealizujących tego modelu.

Konieczność poszerzenia badań nad społeczno-ekonomiczną sytuacją osób nieheteronormatywnych o ośrodki pozamiejskie ma dwojaki charakter i polityczną ważność. Z jednej strony przyczynia się do dekonstrukcji metropolitalnej homonormatywności jako jedynej formy realizacji tożsamości

${ }^{63}$ Badania wśród członków grupy „Wiara i Tęcza” (Instytucjonalny i indywidualny wymiar religijności osób LGBT w Polsce) prowadzi dr Dorota Hall (zob. Hall 2013).

${ }^{64}$ Terminu po raz pierwszy użył Michel Foucault (2010) dla określenia sposobu, w jaki państwo zarządza swoimi obywatelami, produkując jednostki odpowiadające pożądanemu modelowi obywatela przy użyciu określonych technik i racjonalności. Tutaj, terminu używam w odniesieniu do technik zarządzania osobami tworzonych w warunkach wolnorynkowych. Również antropolożka Margot Weiss argumentuje w kontekście seksualnej polityki tożsamościowej, że neoliberalizm jest nie tylko teorią ekonomiczną, ale także rodzajem rządomyślności, który produkuje i uprawomocnia istnienie podmiotów podążających za urynkowionym rozumieniem relacji pomiędzy tym, co publiczne i prywatne (Weiss 2011: 18).

${ }^{65}$ Donham wysuwa w swoim artykule tezę, że jednostki homonormatywne z Republiki Południowej Afryki w momencie fundamentalnych przemian polityczno-gospodarczych mogły na nowo tworzyć swoją tożsamość w oparciu o emancypacyjny model globalnej społeczności gejowskiej, przyjmując jednocześnie nowe kategorie w stwarzaniu siebie. Jest to przykład homonormatywności jako struktury narzucającej jednostkom sposób kreowania swej tożsamości w oparciu o neoliberalizm. Polityka różnorodności (seksualnej, wyznaniowej, światopoglądowej, estetycznej) pozwala jednostkom jednocześnie konstruować siebie, ale w odniesieniu do globalnego modelu. Podobne procesy miały miejsce w Polsce po 1989 roku wraz z modernizacją kraju. 
homoseksualnej i może wpływać na inkluzję i akceptację osób homoseksualnych w mniejszych ośrodkach i na wsi. Z drugiej zaś, przywraca wyrazistość nieoczywistej i zróżnicowanej rzeczywistości społecznej, która wymyka się normatywnym modelom i hierarchizującym etykietom. Mam nadzieję, że nurt badań jakościowych wychodzących poza miejskocentryczną logikę (Struzik 2012, trwające badania "Rodziny z wyboru w Polsce" pod kierownictwem Joanny Mizielińskiej66) pozwoli dostrzec, że neoliberalne konstruowanie podmiotowości i związana z nim metropolitalna homonormatywność nie dominuje w złożoności społecznych realiów, zaś funkcjonowanie społeczeństwa obywatelskiego nie dokonuje się jedynie w zorientowanym na logikę zysków i strat schemacie, gdzie obywatel zmienia się w funkcjonującego samodzielnie, poza społecznością "klienta" czy "konsumenta"67. Przytoczę jeszcze raz słowa Weeksa i podkreślę, że nie ma jednej seksualności: również homoseksualność, choć kreowana przez media (zob. Rams 2011) i kampanie reklamowe jako jednocząca wszystkich ludzi wymykających się heteronormatywnym wzorcom jako homonormatywność, każdorazowo definiowana i negocjowana jest w zależności od usytuowania klasowego, genderowego i szeroko pojętej struktury społecznej, w której podmioty funkcjonują. Homonormatywność silnie sprzężona z neoliberalizmem, który jest nie tylko systemem gospodarczym, ale i stylem życia, może mieć zatem walor emancypacyjny dla jednostek, które utożsamiając się z globalną społecznością legitymizują w lokalnym kontekście swoją tożsamość poprzez uczestnictwo w kulturze homoseksualnej, jak i funkcję wykluczającą w stosunku do tych osób, które nie wpisują się w promowany model homonormatywnej jednostki. Ten ujednolicający model (jego składowymi są: klasa, rasa68, wiek, miejsce zamieszkania) pomija kontekst i warunki, w jakich dyskursy i praktyki nie heteronormatywne są negocjowane, lokalną wiedzę zezwalającą na wytwarzanie zróżnicowanych seksualności, codzienność i doświadczenie wielu osób homoseksualnych, które tego modelu nie reprezentują, czego efektem jest globalizacja i eksternalizacja homonormatywności jako niezależnej i unifikującej odgórnie struktury, ograniczającej się do bardzo wąskiej neoliberalnej racjonalności wolnego rynku.

66 Niektóre z metod badawczych wykorzystanych w projekcie są oparte na paradygmacie badań antropologicznych: obserwacja uczestnicząca, wywiady pogłębione i etnografia codzienności wśród rodzin z wyboru. Zob. http://rodzinyzwyboru.pl [dostęp: 1.06.2014].

67 Obcujemy obecnie z konkurencyjnymi interpretacjami terminu "społeczeństwo obywatelskie". Podczas gdy klasyczny republikanizm doby Rewolucji Francuskiej widział społeczeństwo obywatelskie jako społeczność polityczną, nowe interpretacje przyniosły pisma Hegla czy de Tocqueville`a, którzy opisywali "społeczeństwo obywatelskie" raczej w terminach rynkowych, bliższych liberalizmowi. Obywatele byli wich ujęciach konsumentami spełniającymi własne potrzeby. Marks odświeżył rozumienie społeczeństwa obywatelskiego jako społeczeństwa politycznego, które posiada zdolność do zrzeszania się na rzecz politycznej zmiany. Podczas gdy współcześnie renesans terminu wiąże się w dominującej narracji z działalnością antykomunistycznej opozycji w krajach Europy Wschodniej, w latach 90. zastąpił go neoliberalny dyskurs (a więc nawiązujący do społeczeństwa rynkowego) dotyczący społeczeństwa obywatelskiego (zob. Załęski 2012).

68 Jak wspomniałam wcześniej, szczegółowa analiza uczestnictwa kultury hip-hopowej w debacie wokół małżeństw jednopłciowych mogłaby przyczynić się do poszerzenia tego modelu również o nieheteronormatywne jednostki wśród nieuprzywilejowanej klasy robotniczej, prekariatu (zob. Woltersdorff 2008/2009) czy Afroamerykanów, mieszkańców gett i robotniczych przedmieść dużych metropolii zachodnich. Warto zauważyć, że reklama Microsoftu wykorzystuje utwór białych hip-hopowców, podczas gdy zdecydowana większość raperów zaangażowanych w debatę wokół małżeństw jednopłciowych to osoby czarnoskóre, wywodzące się często ze stereotypowo ukazywanych w dyskursie publicznym jako slumsy i getta dzielnic, takich jak nowojorski Bronx czy Harlem, które nota bene przeistaczają się w zgentryfikowane dzielnice dla miejskiej klasy średniej. 


\section{Bibliografia}

Abramowicz, Marta. 2012. Sytuacja społeczna osób LGB. Analiza danych z badania ankietowego. W: (red.) Makuchowska, Mirosława, Pawlęga, Michał. Sytuacja społeczna osób LGBT. Raport za lata 2010 i 2011. Warszawa: Kampania Przeciw Homofobii, s. 11-100. https://www.kph.org.pl/publikacje/Raport_badania_LGBT_do_netu.pdf; dostęp: 22.03.2014.

Anderson, Benedict. 1997. Wspólnoty wyobrażone. Rozważania o źródłach i rozprzestrzenianiu się nacjonalizmu. Kraków: Znak.

Barrett, Donald C., Pollack, Lance M. 2005. Whose Gay Community? Social Class, Sexual SelfExpression, and Gay Community Involvement. W: The Sociological Quarterly" 46, s. 437-456.

Baudrillard, Jean. 2001. Selected Writings. Stanford: University Press.

Brief of 278 Employers and Organizations Representing Employers as Amici Curiae in Support of Respondent Edith Schlain Windsor (Merits Brief). 2013. http://pl.scribd.com/doc/127567244/12307-Bsac-278-Employers-and-Organizations-Representing-Employers-Copy; dostęp: 22.03.2014.

Brown, Gavin. 2012. Homonormativity: a Metropolitan Concept that Denigrates "Ordinary" Gay Lives. W: „Journal of Homosexuality” 59.7, s. 1065-1072.

Butler, Judith. 2008. Uwikłani w płeć. Tłum. K. Krasuska. Warszawa: Wydawnictwo Krytyki Politycznej.

CBOS. 2013. Stosunek do praw gejów i lesbijek oraz zwiazków partnerskich. Komunikat z Badań Centrum Badania Opinii Publicznej (CBOS). BS/24/2013. Warszawa.

Corporate Equality Index 2013. Human Rights Campaign. http://issuu.com/humanrightscampaign/docs/corporateequalityindex_2013/1?e=1357809/151 5650; dostęp: 22.03.2014.

D'Emilio, John. 1983. Capitalism and Gay Identity. W: (red.) Abelove, Henry, Barale, Aina M, Halperin, David M. The Lesbian and Gay Studies Reader. New York, London: Routledge, s. 467476.

Donham, Donald L. 2012. Wyzwalanie Republiki Południowej Afryki. Unowocześnianie seksu pomiędzy mężczyznami w Soweto. W: (red.) Kościańska, Agnieszka. Antropologia seksualności. Teoria. Etnografia. Zastosowanie. Warszawa: Wydawnictwo Uniwersytetu Warszawskiego, s. 383-402.

Duggan, Lisa. 2002. The New Homonormativity: The Sexual Politics of Neoliberalism. W: (red.) R. Castronovo, Russ, Nelson, Dana D. Materializing Democracy: Toward a Revitalized Cultural Politics. Durham: Duke University Press, s. 175-194.

Dunn, Elizabeth. 2008. Prywatyzując Polskę. O bobofrutach, wielkim biznesie i restrukturyzacji pracy. Warszawa: Wydawnictwo Krytyki Politycznej.

Florida, Richard. 2010. Narodziny klasy kreatywnej. Warszawa: Wydawnictwo Narodowego Centrum Kultury.

Foucault, Michel. 2010. Bezpieczeństwo, terytorium, populacja. Warszawa: Wydawnictwo Naukowe PWN.

- - -. 1995. Historia seksualności. Warszawa: Spółdzielnia Wydawnicza "Czytelnik". 
Gates, Gary J. 2009. Marriage Equality and the Creative Class. Los Angeles: Williams Institute, University of California. http://williamsinstitute.law.ucla.edu/wp-content/uploads/Gates-MACreative-Class-May-2009.pdf; dostęp: 22.03.2014.

- - -, Florida, Richard. 2003. Technology and Tolerance: The Importance of Diversity to HighTechnology Growth. W: (red.) Clark, Terry N. The City as an Entertainment Machine. Elsevier, Oxford: Emerald Group Publishing Limited, s. 199-219.

Gershon, Ilana. 2011. Neoliberal Agency. W: "Current Anthropology” 52.4, s. 537-555.

Giroux, Henry A. 2004. Neoliberalism and the Demise of Democracy: Resurrecting Hope in Dark Times. W: „Dissident Voice”; dostęp: http://www.dissidentvoice.org/Aug04/Giroux0807.htm.

Hall, Dorota. 2013. Religia i nieheteronormatywność: stan debaty akademickiej i wybrane wątki badań prowadzonych w Polsce. W: „Studia Socjologiczne” 3 (210), s. 123-150.

Jabłońska, Zofia. 2011. Sytuacja prawna osób LGBT na rynku pracy - implementacja standardów unijnych do polskiego systemu prawa z uwzględnieniem przepisów Ustawy o wdrożeniu niektórych przepisów UE w zakresie równego traktowania. W: (red.) Śmiszek, Krzysztof. Dyskryminacja ze względu na orientację seksualna i tożsamość płciowa w zatrudnieniu. Warszawa: Kampania Przeciwko Homofobii, s. 90-105.

Kluczyńska, Urszula. 2013. Nienormatywna rodzina heteroseksualna z dzieckiem - opresyjność roli. W: „InterAlia” 8, s. 65-77.

Kościańska, Agnieszka. 2010. Kulturowe konteksty naukowej wiedzy o seksualności. W: (red.) Malewska-Szałygin, Anna, Radkowska-Walkowicz, Magdalena. Antropolog wobec wspótczesności. Warszawa: Instytut Etnologii i Antropologii Kulturowej Uniwersytetu Warszawskiego, s. 227-234.

- - -. 2012a. Czy onanista to też Polak? Debata o masturbacji 1993-1994. „InterAlia” 7. http://www.interalia.org.pl/pl/artykuly/2012_7/12_czy_onanista_to_tez_polak_debata_o_mastur bacji_19931994.htm; dostęp: 15.03.2014.

- - -. 2012b. Kościoły i zwiq̨zki wyznaniowe w Polsce wobec osób LGBT. W: (red.) Makuchowska, Mirosława, Pawlęga, Michał. Sytuacja społeczna osób LGBT. Raport za lata 2010 i 2011. Warszawa: Kampania Przeciwko Homofobii, s. 145-165. http://www.kph.org.pl/publikacje/Raport_badania_LGBT_do_netu.pdf; dostęp: 22.03.2014.

Majka, Rafał. 2010. Lewica, równość, solidarność. Spór o wartości i strategie, http://www.feminoteka.pl/readarticle.php?article_id=839; dostęp: 22.03.2014.

Majka-Rostek, Dorota. 2009. Indywidualizm jako źródło współczesnych przemian rodziny. W: „Kultura i Historia" 16/2009. http://www.kulturaihistoria.umcs.lublin.pl/archives/1459.

- - -. 2010. Homoseksualizm i kapitalizm - klasowy wymiar kultury gejowskiej w Polsce po 1989 roku. W: (red.) Żuk, Piotr. Podziaty klasowe i nierówności społeczne. Refleksje socjologiczne po dwóch dekadach realnego kapitalizmu w Polsce. Warszawa: Oficyna Wydawnicza, s. 153-164.

McCann, Eugene J. 2007. Inequality and Politics in the Creative City-Region: Questions of Livability and State Strategy. W: „International Journal of Urban and Regional Research" 31.1, s. 188-196.

Mizielińska, Joanna, Stasińska, Agata. 2013. Od "wroga rodziny" do jednej z jej form: Rodziny z wyboru we współczesnym polskim dyskursie prasowym. W: „InterAlia” 8, s. 106-128. 
Olssen, Mark. 2008. Understanding the Mechanisms of Neoliberal Control: Lifelong Learning, Flexibility and Knowledge Capitalism. W: (red.) Fejes, Andreas, Nicoll, Katherine. Foucault and Lifelong Learning: Governing the Subject. London: Routledge, s. 34-47.

Sennett, Richard. 2007. Korozja charakteru. Osobiste konsekwencje pracy w nowym kapitalizmie. Warszawa: Wydawnictwo Literackie Muza S.A.

Slany, Krystyna. 2002. Alternatywne formy życia matżeńsko-rodzinnego w ponowoczesnym świecie. Kraków: Nomos.

Somerville, Siobhan. 1998. Scientific Racism and the Invention of the Homosexual Body. W: (red.) Bland, Lucy, Doan, Lora. Sexology in Culture: Labelling Bodies and Desires. Chicago: University of Chicago Press, s. 60-75.

Vance, Carole S. 2007. Konstruktywizm społeczny: kłopoty z historia seksualności. W: (red.) Hryciuk, Renata E., Kościańska, Agnieszka. Gender. Perspektywa antropologiczna, t. 2, Kobiecość, męskość, seksualność. Warszawa: Wydawnictwo Uniwersytetu Warszawskiego, s. 15-32.

Weeks, Jeffrey. 2012. Wynalezienie seksualności. W: (red.) Kościańska, Agnieszka. Antropologia seksualności. Teoria, etnografia, zastosowanie. Warszawa: Wydawnictwo Uniwersytetu Warszawskiego, s. 23- 55.

Weiss, Margot. 2011. Techniques of pleasure: BDSM and the circuits of sexuality. Durham, NC: Duke University Press.

Woltersdorff, Volker. 2008-2009. Queer Subject Economies. Managing Diversity and Precariousness in Neoliberalism. W: „InterAlia” 6, http://www.interalia.org.pl/en/artykuly/20082009_3/04_queer_subject_economies_managing_d iversity_and_precariousness_in.htm; dostęp: 22.03.2014.

- - -. 2007. Neoliberalism and its Homophobic Discontents. W: „InterAlia” 5, http://www.interalia.org.pl/index_pdf.php?lang=en\&klucz=\&produkt=1199739745-773; dostęp: 22.03.2014.

Załęski, Paweł S. 2012. Neoliberalizm i społeczeństwo obywatelskie. Wrocław: Wydawnictwo Naukowe Uniwersytetu Mikołaja Kopernika. 